\title{
IDIOPATHIC RECURRENT CALCIUM UROLITHIASIS (IRCU): Pathophysiology Evaluated in Light of Oxidative Metabolism, Without and With VARIATION OF SEVERAL Biomarkers IN FASTING URINE AND PLASMA -

\author{
A Comparison of Stone-free and -Bearing Male Patients, Emphasizing \\ Mineral, Acid-Base, Blood Pressure and Protein Status*
}

\author{
P. O. Schwille, A. Schmiedl, M. Manoharan, J. Wipplinger
}

Mineral Metabolism and Endocrine Research Laboratory, Departments of Surgery and Urology, University of Erlangen-Nürnberg, Germany

\begin{abstract}
Background: IRCU is traditionally considered as lifestyle disease (associations with, among others, overweight, obesity, hypertension, type-2 diabetes), arising from excess, in $24 \mathrm{~h}$ urine, of calcium (Ca) salts (calcium oxalate $(\mathrm{CaOx})$, calcium phosphate $(\mathrm{CaPi}))$, supersaturation of, and crystallization in, tubular fluid and urine, causing crystal-induced epithelial cell damage, proteinuria, crystal aggregation and uroliths.

Methods: Another picture emerges from the present uncontrolled study of 154 male adult IRCU patients (75 stone-bearing (SB) and 79 age-matched stonc-free $(\mathrm{SF})$ ), in whom stone-forming and other parameters in fasting urine and plasma were contrasted with five biomarkers (see footnote) of oxidative metabolism (OM), without and with variation of markers.

Results: 1) In SB vs. SF unstratified OM biomarkers were statistically unchanged, but the majority of patients was overweight; despite, in SB vs. SF urine $\mathrm{pH}$, total and non-albumin protein concentration were elevated, fractional urinary uric acid excretion and blood bicarbonate decreased, whereas urine volume, sodium, supersaturation with $\mathrm{CaOx}$ and $\mathrm{CaPi}$ (as hydroxyapatite) were unchanged; 2) upon variation of OM markers (strata below and above median) numerous stone parameters differed significantly, among others urine volume, total protein, $\mathrm{Ca} / \mathrm{Pi}$ ratio, $\mathrm{pH}$, sodium, potassium, plasma $\mathrm{Ca} / \mathrm{Pi}$ ratio and parathyroid hormone, blood pressure, renal excretion of non-albumin protein and other substances; 3) a significant shift from $\mathrm{SF}$ to $\mathrm{SB}$ patients occurred with increase of urine $\mathrm{pH}$, decrease of blood bicarbonate, and increase of diastolic blood pressure, whereas increase of plasma uric acid impacted only marginally; 4) in both SF and SB patients a strong curvilinear relationship links a rise of urine $\mathrm{Ca} / \mathrm{Pi}$ to urine $\mathrm{Ca} / \mathrm{Pi}$ divided by plasma $\mathrm{Ca} / \mathrm{Pi}$,
\end{abstract}

\footnotetext{
* This work is dedicated to Professor Alfred Sigel, former head of Department of Urology, University of ErlangenNürnberg, Germany, for his long-standing interest in and strong support of renal stone research.
}

but in SB urine $\mathrm{Ca} / \mathrm{Pi}$ failed to correlate significantly with urine hydroxyapatite supersaturation; 5) also in $\mathrm{SB}$, plasma $\mathrm{Ca} / \mathrm{Pi}$ and urinary nitrate were negatively correlated, whereas in $\mathrm{SF}$ plasma $\mathrm{Ca} / \mathrm{Pi}$ ratio, $\mathrm{P} T H$ and body mass index correlated positively; 6) multivariate regression analysis revealed that PTH, body mass index and nitrate together could explain $22(\mathrm{p}=$ $0.002)$ and only $7(p=0.06)$ per cent of variation of plasma $\mathrm{Ca} / \mathrm{Pi}$ in $\mathrm{SF}$ and $\mathrm{SB}$, respectively.

Conclusions: In IRCU a) numerous constituents of fasting urine, plasma, blood and blood pressure change in response to variation of OM biomarkers, suggesting involvement of OM imbalance as factor in functional deterioration of tissue; b) in the majority of patients a positive exponential relationship links urine $\mathrm{Ca} / \mathrm{Pi}$ to urine $\mathrm{Ca} / \mathrm{Pi}$ divided by plasma $\mathrm{Ca} / \mathrm{Pi}$, presumably to accumulate $\mathrm{Ca}$ outside tubular lumen, thereby minimizing intratubular and urinary $\mathrm{Ca}$ salt crystallization; c) alteration of interactions of low urine nitrate, $\mathrm{P} T H$ and $\mathrm{Ca} / \mathrm{Pi}$ in plasma may be of importance in formation of new Ca stone and co-regulation of dynamics of blood vasculature; d) overweight, combined with OM-modified renal interstitial environment appears to facilitate these processes, carrying the risk that $\mathrm{CaPi}$ mineral develops within or/and close to blood vessel tissue, and spreads towards urothelium.

For future rescarch focussing on IRCU pathogenesis studies are recommended on the role of affluent lifestyle mediated renal ischemia, mild hypertensive nephropathy, rise of uric acid precursor oxypurines and uricemia, clarifying also why loss of significance of interrelationships of OM biomarkers with traditional $\mathrm{Ca}$ stone risk factors is characteristic for SB patients.

\section{OM biomarkers}

Plasma uric acid - Discussed as scavenger of reactive oxygen species, but also as donator (via the xanthine oxido-reductase reaction)

Urinary malonedialdehyde - Accepted as indicator of peroxidation of lipids within biological cell membranes 
Urinary nitrate - Accepted as indicator of vasodilation-mediating nitric oxide production by blood vessel endothelium

Urinary malonedialdehyde/Plasma uric acid - 'Tentative markers of oxidant/antioxidant imbalance

Urinary nitrate/Plasma uric acid - Tentative markers of oxidant/antioxidant imbalance

Key words: Idiopathic Recurrent Calcium Urolithiasis - New stones absent or present - Oxidative and nitrative metabolism - Variation of biomarkers - State of stone parameters

\section{IN'TRODUCTION}

The pathophysiology of IRCU is multifactorial, including both influences of environment and intrinsic metabolism [1]; details are insufficiently understood and a unifying concept is not in sight. In work published until present two opposing theories compete: One, worked out between $1960-1980$ [see ref. 2], is based on physico-chemistry, ascribing formation of calcium (Ca) stones to supersaturation (SS) of tubular fluid and urine with more or less soluble salts and substances such as $\mathrm{Ca}$ oxalate $(\mathrm{CaOx}), \mathrm{Ca}$ and inorganic phosphate (CaPi), uric acid (UA), followed by crystallization, crystal adhesion to and incorporation by tubular epithelial cells, with microlith formation being a secondary step $[2,3]$. Another theory, formulated earlier and at that time neglecting urinary supersaturation and crystallization as primary events [4], favors stone formation as process starting from renal interstitial areas (so-called plaques) [4,5] which, from yet unknown reasons, are characterized by hydroxyapatite (HAP) content [6]. This crystallized Ca-rich mineral forms preferentially in plaques of stone forming males [5] from excess of $\mathrm{Ca}$ over $\mathrm{Pi}(\mathrm{Ca} / \mathrm{Pi})$ [7], i.e., independent of fluid volume (interstitial fluid, urine) and urinary SS(U-SS)-HAP. Also, generation of HAP-containing plaques from amorphous $\mathrm{CaPi}$ requires an alkaline environment [8], as prevails in renal interstitial tissue. Plaques were described as located in close vicinity to basolateral membranes of tubular epithelium and blood vessels (vasa recta) $[4,6,9]$, and high blood pressure $(\mathrm{BP})$ was found to be the only clinical parameter correlating with plaques [9]. Thus, investigators of IRCU pathogenesis are forced to consider one or more systemic factors the presence of which may or may not lead to clinically detectable stone as endpoint, independent of a urinary crystal- and stone-initiating role of urinary SS. To approach a solution, better knowledge of the metabolic environment of $\mathrm{Ca}$ stone-bearing (SB) vis-à-vis stone-free (SF) patients appears indispensable, a goal to achieve by a much broader laboratory program [10] than hitherto practiced in clinical stone centers. More specifically, information is required not only on the state of renal glomerular and tubular function, urine $\mathrm{Ca}, \mathrm{Pi}, \mathrm{Ca} / \mathrm{Pi}$, SS-HAP, SS-CaOx and proteins, but also on minerals and proteins in systemic plasma, blood acid-base data, $\mathrm{BP}$, body mass index (BMI) and age, thoughts insufficiently pursued by us in earlier work $[10,11]$.

From database of analyzed biosamples of our IRCU patients a preliminary impression was that SB and SF patients differ in several regards: In SB, but not SF patients high HAP supersaturation of fasting urine was found associated with higher urine $\mathrm{pH}$ and higher blood bicarbonate $\left(\mathrm{HCO}_{3}{ }^{-}\right)$; when HAP supersaturation was low, the urinary molar $\mathrm{Ca} / \mathrm{Pi}$ ratio was low too, and vice versa; conversely, in SF patients lower plasma uric acid (UA) was found associated with renaltubular loss of UA, and uricemia appeared to vary inversely with U-SS-HAP, directly with BP. Knowledge on the role(s) played by UA, especially as biomarker of oxidative metabolism (OM), i.e., as factor in the maintenance of oxidant/antioxidant balance is incomplete in a number of diseases [12,13]; on the other hand, damage of vascular tissue and modulation of BP are sequelae of overproduction of reactive oxygen species (ROS) and/or deficient ROS scavenging, or both [14, 15]. From such observations we reasoned that malregulation of OM could be a systemic factor capable of paving the way for development of a metabolic environment, in turn allowing that disordered $\mathrm{Ca}$ and $\mathrm{Pi}$ levels develop in blood and urine, with formation of new Ca stone, and eventually, a rise of BP as secondary events. To obtain better information, a platform of data is needed from which new testable hypotheses can be formulated.

The following uncontrolled study is an extension of, and to some degree summarizing, our previous reports in this area $[11,16-20]$. The focus was on several questions: 1) are the levels of bio markers (see below) different, depending on whether SF or SB patients are studied; if not, in which other regards are these subsets of patients different; 2) are traditional $\mathrm{Ca}$ stone risk parameters subject to modulation by variation of bio markers; 3) which factors influence the frequency distribution of SF and SB patients; 4) study of interrelationships of variables and, if helpful in understanding events involved in formation of new $\mathrm{Ca}$ stone, to comment a possible initiating role of OM.

\section{MÁTERIAL AND ME'THODS}

\section{PATIFNTS}

The database of a total of 154 adult middle-aged male IRCU patients allowed to recruit a roughly equal number for SB and SF subsets. Details of the general criteria of participants, including the clinically assessed actiyity of Ca stone formation (ASFP) in the two years preceding the laboratory examination (see below) were earlier described $[11,16]$. In brief: European residents of the North Bavarian region in Germany, experience of more than one stone episode in the past, IRCU diagnosis by KUB, stone analysis by X-ray diffractometry, petrographic microscopy and wet-chemical analysis, respectively, with stone analysis confirming that in approx. two thirds $\mathrm{CaOx}$ (as di- and mono-hydrate) was dominant over $\mathrm{CaPi}$ (as HAP or precursors), despite absence of $\mathrm{CaO}$ x crystals but abundance of noncrystallized (amorphous) $\mathrm{CaPi}(\mathrm{Ca} / \mathrm{Pi} \leq 1.0)$ in fasting urine [21] as studied herein (see below). Additional requirements were absence of gastrointestinal surgeries, especially gut resections, urinary tract infection (bacillus proteus, others), hematuria (dipstick-positive urine), oxaluria ( $\geq 0.5 \mathrm{mM}$ in $24 \mathrm{~h}$ urine), other systemic disorders (pHPT, RTA, diabetes mellitus, gout), 
cystitis and urethritis, with the latter two minimizing that post-renal proteinuria was caused by them. Finally, all patients negated anti-stone medication, vitamin and mineral supplementation of daily food during the past 6 weeks, and all wcre advised to omit intake of oxalate- and salt (sodium chloride)-rich food and to drink but tap water during the $12-15 \mathrm{~h}$ night period preceding the ambulatory laboratory examination (sec below). $\Lambda$ fter the study goals were communicated, all agreed to investigations carried out according to the principles of the Declaration of Helsinki.

\section{Ci.inical Laboratory Program}

All data reported herein were obtained from a standardized ambulatory examination, as outlined in detail elsewhere [10]. The basis was the fasting period [10] during which patients stayed in the laboratory (after at home collection of a $24 \mathrm{~h}$ urine that scrves for exclusion of mild hyperoxaluria), measurement of blood pressure (twice in a recumbent position at the nondominant forearm), stimulation of diuresis by drinking of $300 \mathrm{ml}$ distilled water to achieve approx. $1 \mathrm{ml}$ urine flow per min, puncture of an car vein (for immediate blood gas analysis), withdrawal of venous blood without stasis from the pre-warmed non-dominant forearm, and bladder voiding. Aliquots of plasma and paper-filtered urine from the exactly timed $2 \mathrm{~h}$ fasting period [10] were prepared, and either immediately analyzed or stored at $-80^{\circ} \mathrm{C}$.

\section{OM BIOMARKERS}

Three substances were selected, in addition two ratios:

1) UA concentration in plasma; at present widely conceived as ROS scavenger [22, 23], there are arguments that it is not this mode alone through which plasma UA contributes to OM balance or imbalance $[23,24]$ : The cytoplasmic UA-synthesizing xanthine (XA) oxido-reductase (XOR) is renally expressed, but outside glomerula [26], releases ROS [25] and thereby diminishes the ROS scavenging capacity of UA; in addition, ab initio low uricemia, for example owing to defective renal tubular UA reabsorption [27], can account for insufficient ROS scavenging by UA. Therefore, erroneous conclusions may be drawn from isolated consideration of plasma UA in vivo [22].

2) Malonedialdehyde (MDA), a major product from ROS interactions with lipid and lipoprotein (peroxidation) containing cell membranes [28]; high MDA is considered to indicate deterioration of trans-membrane transport function for vitally important substances, Ca ions included [29].

3) Nitrate (NIT), an oxidation product of the blood microvasculature dilating nitric oxide (NO) of endothelial origin [30]; urinary NIT is accepted as marker of total NO production $[31,32]$. However, NO can act also as free radical [nitrative stress; 33, 34] and high NO production can exert dual actions $[34,35]$.

4) The ratios MDA/UA and 5) NIT/UA were introduced as possible markers of oxidant/antioxidant imbalance, attempting to disentangle the above-mentioned intertwined in vivo situation (simultaneous presence of oxidants and antioxidants).

\section{STUdy Disign}

The overlap of patients in present and previous work, following substantially different strategies [19, 20], was about $95 \%$. The study was retrospective, observational, cross-sectional and correlative (healthy control individuals were not included). The ranges of ASFP, age and BMI (measured in laboratory), were kept roughly comparable in $\mathrm{SB}$ and $\mathrm{SF}$. Results were presented in five sections, with considerable complementary and supportive data packages (from sections $3,4,5$ ) being incorporated into APPENDIX (APP; I, II, III).

\section{Anaidses, Calculations, Statistics}

Routine methods or well-established techniques were utilized for analyzing urine, plasma and blood. Most of these were previously reported $[10,11,16,20]$, including the 14 analytes entering the calculation (see below) of urinary supersaturation (U-SS), urinary total protein and albumin (colorimetry and immuno-nephelometry, respectrively). Exceptions were the use of high performance liquid chromatography for $\mathrm{Ox}$ in plasma ultrafiltrate [36], urinary MDA [37], NIT [38], hypoxanthine (HX) and XA (both reported as indicators of hypoxia and hypoxia-mediated cellular ATP depletion $[39,40]$, commercial kits for radioimmunoassays of plasma intact (amino acid sequence 1-84) parathyroid hormone (PTH), 1,25-dihydroxyvitamin $\mathrm{D}_{3}\left(1,25(\mathrm{OH})_{2} \mathrm{D}\right)$ and arginine-vasopressin (AVP), the former two bought from Nichols Institute, Bad Nauheim, Germany, the latter from Diagnostics Systems Laboratories, Sinsheim, Germany. Plasma osmolarity was measured by freezing point depression (Osmometer, Knauer, Berlin, Germany).

Calculations included plasma non-albumin protein (N-Alb-P; as difference between total protein and albumin), U-SS-HAP and U-SS-CaOx (expression as free energy (DG), see ref. [41]), renal clearance of endogenous creatinine, fractional excretion (FE) of minerals and other substances. In numerous instances $\log _{10}$ transformation of numerical values led to symmetric distribution, allowing application of Student's t-test. Catcgorical data were compared by Chi-square and the more sensitive Fisher's exact test. For practical purposes mean values (SE) are given, exceptionally mean and range. The level of significance of differences was taken as $\mathrm{p} \leq 0.05$. From large matrices (simple correlations), constructed for unclassified IRCU $(\mathrm{SF}+\mathrm{SB})$ and separately for SF and SB subsets, interrelations and determinants (multivariate logistic (forward and backward) regression analysis; MRA) were identified using the software STATISTICA (Statsoft, Tulsa, OK; USA).

\section{RESULTS}

\section{SECTION 1}

\section{Unstratified OM biomarkers in SB and SF subsets of IRCU}

In SB and SF patients the mean values of the five markers, age and BMI were statistically indistinguishable, and so was the mean higher ASFP in SB subset. BMI of the 154 patients was as follows: overweight 
Table 1. Biomarkers of oxidative metabolism $(A-E)$ in the SB and SF subsets of 154 IRCU male patients. For other abbreviations and further informations see footnotes and text.

\begin{tabular}{|c|c|c|c|c|c|}
\hline & \multicolumn{5}{|l|}{ Code $^{a}$} \\
\hline & $\mathrm{A}^{*}$ & B & C & D & $\mathbf{E}$ \\
\hline \multicolumn{6}{|l|}{ SB: } \\
\hline$n^{b}$ & 75 & 75 & 75 & 65 & 65 \\
\hline Range of values & $159-535$ & $27-315$ & $74-1051$ & $48-548$ & $132-1606$ \\
\hline Mean & 355 & 132 & 312 & 132 & 389 \\
\hline Age; y & $43.0(1.9)^{\mathrm{c}}$ & $42.7(1.9)$ & $42.7(1.8)$ & $42.4(2.0)$ & $42.6(2.0)$ \\
\hline $\mathrm{BMI} ; \mathrm{kg} /(\mathrm{m})^{2}$ & $26.5(0.4)$ & $26.6(0.4)$ & $26.5(0.4)$ & $26.6(0.4)$ & $26.6(0.4)$ \\
\hline ASFP; score & $40(6)$ & $40(6)$ & $40(6)$ & $40(7)$ & $41(7)$ \\
\hline \multicolumn{6}{|l|}{ SF: } \\
\hline $\mathrm{n}$ & 79 & 79 & 79 & 52 & 52 \\
\hline Range of values & $217-593$ & $25-345$ & $86-902$ & $28-489$ & $87-1338$ \\
\hline Mean & 360 & 131 & 384 & 140 & 390 \\
\hline $\mathrm{p}$-value & 0.18 & $0.24^{\mathrm{d}}$ & $0.17^{\mathrm{d}}$ & $0.32^{d}$ & $0.20^{\mathrm{d}}$ \\
\hline Age; y & $40.7(1.8)$ & $40.4(1.8)$ & $40.6(1.8)$ & $42.8(2.2)$ & $42.6(2.2)$ \\
\hline $\mathrm{BMI} ; \mathrm{kg} /(\mathrm{m})^{2}$ & $26.1(0.4)$ & $26.1(0.5)$ & $26.1(0.4)$ & $26.4(0.5)$ & $26.3(0.5)$ \\
\hline ASFP; score & $35(5)^{d}$ & $34(5)^{d}$ & $34(6)^{d}$ & $32(6)^{d}$ & $32(7)^{d}$ \\
\hline
\end{tabular}

${ }^{\text {a }}$ : Code (substance(s), abbreviation, dimension, median) as follows:

A - Uric acid in plasma, P-UA, $\mu \mathrm{M} \cdot \mathrm{I}^{-1}, 348$

B - Malonedialdehyde in urine, U-MDA, nM/2 h, 123

C - Urinary malonedialdehyde/plasma uric acid, U-MDA/P-UA, $\mathrm{nM} / \mathrm{mM} \cdot \mathrm{I}^{-1}, 337$

D - Urinary nitrate, U-NIT, $\mu \mathrm{M} / 2 \mathrm{~h}, 120$

E - Urinary nitrate/plasma uric acid, U-NIT/P-UA, $\mu \mathrm{M} / \mathrm{mM} \cdot 1^{-1}, 332$

${ }^{\mathrm{b}}$ : number of patients per marker

: data are mean (SE)

d: statistical comparison with SB based on $\log _{10}$ data

*: in codes A - E the limits of normalcy in 10 healthy male volunteers of the authors' laboratory are: $<420$ (A); $<110$ (B); <375 (C); <314 (D); <1170 (E).
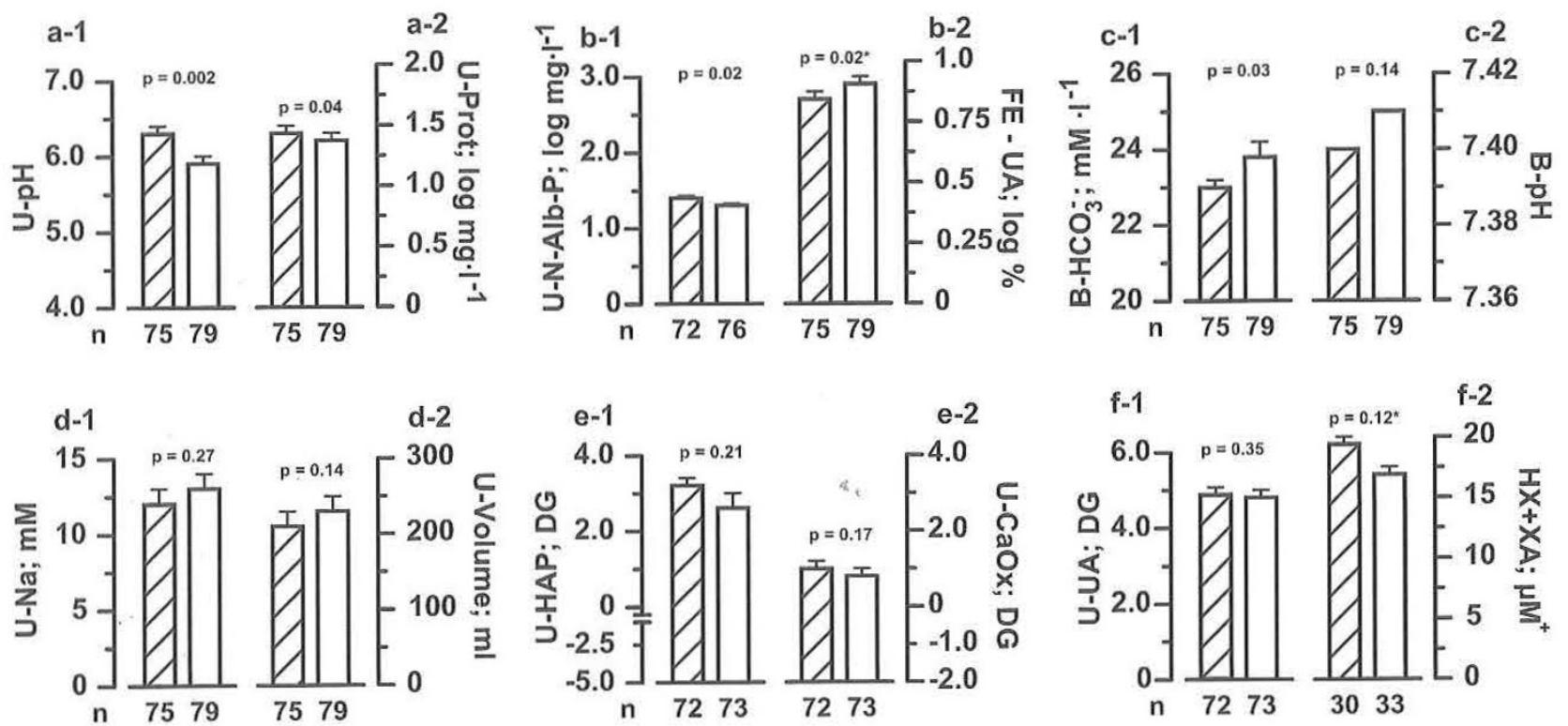

Fig.1. Major characteristics of SB- (hatched bars) vs. SF- (light bars) patients. U: fasting urinc; B: fasting blood; FE: renal fractional excretion (conceived as indicator of the capacity of tubules to lose or reclaim UA); for other abbreviations see below and text. Note that negative DG (HAP, $\mathrm{CaOx}$ ) by definition mean urine undersaturation (synonymous solubility, i.e. no solid formation and dissolution of preformed solid (41)). +: sum of urinary UA precursor oxypurine (HX: hypoxanthine; XA: xanthine) excretion rates; *: based on $\log _{10}$ data; n: number of patients.

(BMI $\left.\geq 25.0-30.0 \mathrm{~kg} /(\mathrm{m})^{2}\right)$ was the dominant $\mathrm{seg}$ ment (SB $\mathrm{n}=51, \mathrm{SF} \mathrm{n}=42)$, normal-weight (BMI $<25.0 \mathrm{~kg} /(\mathrm{m})^{2} ; \mathrm{SB} \mathrm{n}=19$, SF $\mathrm{n}=32$ ), obesity (BMI
$>30.0 \mathrm{~kg} /(\mathrm{m})^{2}, \mathrm{SB} \mathrm{n}=5, \mathrm{SF} \mathrm{n}=5$ ), together contrasting with reports on obesity as a major risk factor of renal stone formation $[42,43]$. 


\section{SECTION 2}

\section{Other characteristics of SB and STi subsets}

Despite statistically indistinguishable OM biomarkers (Table 1), SB and SF subsets differ significantly in several regards (Fig. 1; upper row): increase of urinary $\mathrm{pH}$, concentration of total protein and N-Alb-P, decrease of FE-UA and $\mathrm{B}-\mathrm{HCO}_{3}{ }^{-}$; only insignificantly different were (Fig. 1, lower row) U-sodium (Na), Uvolume, U-SS-HAP, U-SS-CaOx, U-SS-UA, summed excretion of UA precursor oxypurines, and so was plasma AVP (mean values 5.1 (SB) and 4.5 (SF) pg $\mathrm{ml}^{-1}$, respectively).

\section{SECTION 3}

Strata Lom (L) and High (H) of OM biomarkers, systemic and renal response parameters

Tables $2 a$ and $2 b$, APP I and II give the data as associated with the markers (codes $A-E$, strata of $P$ UA, U-MDA, U-MDA/P-UA, U-NI'T, U-NIT/P-UA). Stratification left unchanged BMI, ASFP and C-Cr (as crude marker of glomerular filtration rate), contrasting with change of numerous other parameters.

Code A: The stratum $\mathrm{H}$ patients of P-UA exhibited decrease ( $\mathrm{p} \leq 0.05$ vs. $\mathrm{L}$ ) of U-volume, U-pH, U-SSHAP, U-N-Alb-P, U-Ca, U-xanthine, U-citrate (Cit), U-magnesium $(\mathrm{Mg})$, FE-UA, FE-Cit; there was increase ( $\mathrm{p} \leq 0.05$ vs. L) of U-SS-UA, plasma (P) concentration of N-Alb-P.

Code B: The stratum $\mathrm{H}$ patients exhibited increase of age, diastolic (D-) and systolic BP, B- $\mathrm{HCO}_{3}{ }^{-}$and $\mathrm{B}$ $\mathrm{pH}, \mathrm{U}$-volume, sum of U-sodium $(\mathrm{Na})$ and $\mathrm{U}$-potassium $(\mathrm{K}),(\mathrm{Ca} / \mathrm{Pi}) / \mathrm{Cit},(\mathrm{Ca} / \mathrm{Pi}) / \mathrm{Mg}$ - both ratios discussed as inhibitors respectively promoters of the transformation of poorly crystallized $\mathrm{CaPi}$ to $\mathrm{Ca}$-rich HAP crystals [20] - U-UA, U-Cit, U-Na, U-K, U-Mg, $\mathrm{P}-\mathrm{Mg}$, FE-UA, FE-Ox, FE-K; there was decrease of SS-UA, SS-CaOx (but not SS-HAP), P-PTH and PAVP.

Code C: The stratum H patients often exhibited changes similar to those mentioned above for the stratum $\mathrm{H}$ of U-MDA alone (code B); however, dissimilar were the borderline only increase of systolic $\mathrm{BP}$, significant increase of U-N-Alb-P, U-Ca, U-Pi, U-XA, FE-Na, FE-Mg.

Code D: The stratum $\mathrm{H}$ patients exhibited increase of U-volume, urine excretion of summed alkali metals, U- $(\mathrm{Ca} / \mathrm{Pi}) / \mathrm{U}-\mathrm{Cit}, \mathrm{P}-\mathrm{Pi}$ concentration and P-Osmolarity, U-K and U-Mg; there was decrease of U-SSUA, U-SS-CaOx, U-SS-HAP, U-Ox, P-PTH and P$\mathrm{Ca} / \mathrm{P}-\mathrm{Pi}$ ratio.

Code E: The stratum $\mathrm{H}$ vs. I patients also exhibited changes similar to those observed for stratum $\mathrm{H}$ of $\mathrm{U}$ NIT alone (code D), with a few important exceptions: increase of U-N-Alb-P, U-Pi, U-XA, P-Pi, P-Ox, but decrease of $\mathrm{U}-\mathrm{Ca} / \mathrm{Pi}$ and this ratio divided by $\mathrm{Ca} / \mathrm{Pi}$ in plasma (in Table $2 \mathrm{~b}$ and the following text denoted $\left.\mathrm{U}_{\mathrm{N}} / \mathrm{P}_{\mathrm{N}}\right)$; there was borderline decrease of U-SS-HAP and P-PTH.

On the basis of above changes the shaded positions in Tables $2 a$ and $2 b$, APP I and II are conceived as hypothetical frontier ("red line") in IRCU pathogenesis.
SECIION 4

\section{Frequency distribution of SF and SB subsets}

A scries of parameters was selected from Fig. 1 (U$\mathrm{pH}, \mathrm{B}-\mathrm{HCO}_{3}^{-}$, U-N-Alb-P, FE-UA, but omitting urinary total protein concentration), Table $2 \mathrm{a}$ (P-UA, Uvolume, $\mathrm{D}-\mathrm{BP}, \mathrm{U}_{\mathrm{N}} / \mathrm{P}_{\mathrm{N}}, 10^{3} \times\left(\frac{\mathrm{U}-\mathrm{N}-\mathrm{Alb}-\mathrm{P}}{\mathrm{P}-\mathrm{N}-\mathrm{Alh}-\mathrm{P}}\right)($ in the following text denoted as $\left.\mathrm{U}_{\mathrm{NP}} / \mathrm{P}_{\mathrm{NP}}\right), \Lambda \mathrm{PP} I(\mathrm{U}-\mathrm{Na}$ ); stratification of these parameters according to medians allowed to identify those parameters that predispose for a shift of $\mathrm{SF}$ to SB patients (Table 3). Accordingly, only U-pH and D-BP (positive), and $\mathrm{B}-\mathrm{HCO}_{3}^{-}$(negative) impacted significantly upon SB frequency, whereas the impact of P-UA and P-N-Alb-P, U-volume and U-NAlb-P was borderline (by Fisher's exact test); other parameters, including the rest of OM biomarkers, U-SS$\mathrm{CaOx}, \mathrm{U}-\mathrm{SS}-\mathrm{HAP}, \mathrm{U}-\mathrm{SS}-\mathrm{UA}$ (all not listed) did not impact at all ( $\mathrm{p}$-values $>0.10)$.

\section{SECIIION 5}

Simple correlations, MRAs

To examine whether reports urging for change of paradigms in this disorder $[8,44-46]$ are justified, the focus of the section was on interdependencies of variables. From large correlation matrices (mentioned in Methods chapter; not shown) and the ranking of parameters underlying the SF and SB distribution frequency (see Table 3 ) several blocks of paired observations were sclected and appropriate terms coined (see APP III, columns SF and SB): "Acid-Base", "Blood pressure, Uric acid", "Protein", "Calcium". As regards block "Calcium", strong positive correlations in both $\mathrm{SF}$ and $\mathrm{SB}$ link $\mathrm{U}_{\mathrm{N}} / \mathrm{U}-\mathrm{Cit}$ and $\mathrm{U}_{\mathrm{N}} / \mathrm{U}-\mathrm{Mg}$ to $\mathrm{Log}$ $\mathrm{U}_{\mathrm{N}} / \mathrm{P}_{\mathrm{N}} ;$ PTH and $1,25(\mathrm{OH})_{2} \mathrm{D}$ also correlated directly in SB and SF, indicating intact functional axis between these two parameters; however, in SB, not SF, PTH was significantly negatively correlated to U-NIT and U-NIT/P-UA, and in both SF and SB the insignificant correlation of $\mathrm{P}_{\mathrm{M}}$ and $\mathrm{U}_{\mathrm{M}}(\mathrm{r}=0.13$ and $0.12, \mathrm{p}=0.24$ and 0.29 , for $\mathrm{SF}$ and $\mathrm{SB}$, respectively, not shown in APP III) suggests dysregulation of extracellular Ca and Pi homeostasis. Regarding this point, transparency was improved by relating $\log \mathrm{U}_{\mathrm{N}} / \mathrm{P}_{\mathrm{M}}$, the ratio felt to reflect imbalance of $\mathrm{Ca}$ and $\mathrm{Pi}$ in urine and/or plasma (Table $2 \mathrm{~b}$, code $\mathrm{E}$ ), to numerical values of $\mathrm{U}_{\mathrm{N}}, \mathrm{U}-\mathrm{SS}$ $\mathrm{CaO}$, U-SS-HAP, U-Na, B-HCO ${ }_{3}{ }^{-}$and D-BP (Fig. 2, panels $1 \mathrm{a}$ and $1 \mathrm{~b}$ to $6 \mathrm{a}$ and $6 \mathrm{~b}$ ): In panel $2 \mathrm{a}$ and $2 \mathrm{~b}$ the vast majority of SF and SB paticnts clusters below the value 1.0 of $\mathrm{U}_{\mathrm{M}}$ molarity, linked to $\mathrm{Log} \mathrm{U}_{\mathrm{M}} / \mathrm{P}_{\mathrm{M}}$ via a curvilinear (log-linear; not shown) relationship; yet with respect to U-SS-CaOx (panel 1a, 1b) most patients exhibit positive values, viz cluster within the low area of metastability, contrasting with U-SS-HAP (panel 3a, 3b); furthermore, in SB patients there is loss of significance of positive correlations (U-SS-HAP, U$\mathrm{Na}, \mathrm{B}-\mathrm{HCO}_{3}{ }^{-}$; panels $3 \mathrm{~b}$ to $5 \mathrm{~b}$ ) and between $\mathrm{Log}$ $\mathrm{U}_{\mathrm{N}} / \mathrm{P}_{\mathrm{M}}$ and $\mathrm{D}-\mathrm{BP}$ an inverse significant correlation emerges (panel 6b). Notably, ASFP, U-Na, P-Osmolarity, P-AVP in both subsets of patients failed to correlate significantly with any of the variables listed in APP III.

According to MRAs, including significant $(\mathrm{p} \leq 0.05)$ correlations from each of the four blocks in APP III 
Table $2 a$. General features, ASFP and renal function (Kidney), blood acid-base status (Blood), and urine components (Urine) of the IRCU patients as found associated with the strata Low (L) and High $(\mathrm{H})$ of 5 markers of OM; for abbreviations and medians of markers coded A - E see footnotes of Table 1. Data are mean (SE); [ ]: number of observations. For other abbreviations and further informations see footnotes and text.

\begin{tabular}{|c|c|c|c|c|c|c|c|c|c|c|c|c|c|c|c|c|}
\hline \multirow[b]{2}{*}{ Code } & \multirow[b]{2}{*}{$\begin{array}{l}\text { Markers } \\
\text { Strata }\end{array}$} & \multirow[b]{2}{*}{$N^{*}$} & \multicolumn{2}{|c|}{ General features } & \multirow[b]{2}{*}{$\begin{array}{l}\text { Systolic BP } \\
\mathrm{mm} \mathrm{Hg}\end{array}$} & \multirow[b]{2}{*}{$\begin{array}{l}\text { Diastolic BP } \\
\mathrm{mm} \mathrm{Hg}\end{array}$} & \multicolumn{2}{|l|}{ Kidney } & \multicolumn{2}{|l|}{ Blood } & \multicolumn{6}{|l|}{ Urine } \\
\hline & & & Age & $\begin{array}{l}\text { BMI } \\
\mathrm{kg} /(\mathrm{m})^{2}\end{array}$ & & & $\begin{array}{l}\text { ASFP } \\
\text { score }\end{array}$ & $\begin{array}{l}\mathrm{C}-\mathrm{Cr}^{* *} \\
\mathrm{ml} / \mathrm{mir}\end{array}$ & $\begin{array}{l}\mathrm{HCO}_{3}^{-} \\
\mathrm{mM} \cdot \cdot^{-1}\end{array}$ & $\mathrm{pH}$ & $\mathrm{pH}$ & $\begin{array}{l}\text { Volume } \\
\mathrm{ml}\end{array}$ & $\begin{array}{l}\mathrm{Na}+\mathrm{K} \\
\mathrm{mM}\end{array}$ & $\begin{array}{l}\text { SS-UA } \\
\text { DG }\end{array}$ & $\begin{array}{l}\text { SS-CaOx } \\
\text { DG }\end{array}$ & $\begin{array}{l}\text { SS-HAP } \\
\text { DG }\end{array}$ \\
\hline \multirow[t]{4}{*}{ A } & P-UA & & & & & & & & & & & & & & & \\
\hline & L 307(4) & 78 & $43(1)$ & $26.0(0.3)$ & $126(2)[65]$ & $81(1)[65]$ & $33(3)$ & $112(3)$ & $23.6(0.2)$ & $7.40(0.0)$ & $6.23(0.09)$ & $246(18)$ & $21(0.8)$ & $4.5(0.2)[74]$ & $0.9(0.1)[74]$ & $3.6(0.3)[74]$ \\
\hline & $\mathrm{H} 408(6)$ & 76 & $40(1)$ & $26.6(0.3)$ & $128(2)[65]$ & $83(1)[65]$ & $41(5)$ & $110(2)$ & $23.3(0.3)$ & $7.40(0.0)$ & $6.02(0.09)$ & $195(15)$ & $20(1.1)$ & $5.3(0.2)[71]$ & $1.1(0.1)[71]$ & $2.2(0.4)[71]$ \\
\hline & $\mathrm{p}<0.001$ & & 0.11 & 0.07 & 0.34 & 0.22 & $0.09^{d}$ & 0.23 & 0.18 & 0.37 & 0.04 & 0.02 & 0.08 & 0.002 & 0.20 & 0.003 \\
\hline \multirow[t]{4}{*}{ B } & U-MDA & & & & & & & & & & & & & & & \\
\hline & L $89(2)$ & 77 & $40(1)$ & $26.2(0.3)$ & $124(2)[65]$ & $80(1)[65]$ & $37(5)$ & $112(2)$ & $23.1(0.3)$ & $7.40(0.0)$ & $6.05(0.09)$ & $162(13)$ & $18(0.7)$ & $5.2(0.2)$ & $1.3(0.1)$ & $3.1(0.4)$ \\
\hline & H $173(5)$ & 77 & 43(1) & $26.4(0.3)$ & $130(3)[65]$ & $85(2)[65]$ & $37(3)$ & $110(2)$ & $23.9(0.2)$ & $7.41(0.0)$ & $6.20(0.09)$ & $280(18)$ & $23(1.1)$ & $4.5(0.2)$ & $0.6(0.1)$ & $2.7(0.3)$ \\
\hline & $\mathrm{p}<0.001$ & & 0.03 & 0.26 & 0.03 & 0.01 & $0.32^{d}$ & 0.23 & 0.02 & 0.005 & 0.13 & $<0.001$ & 0.001 & 0.003 & $<0.001$ & 0.19 \\
\hline \multirow[t]{4}{*}{ C } & U-MDA/P-UA & & & & & & & & & & & & & & & \\
\hline & L 244(7) & 77 & $40(1)$ & $26.3(0.3)$ & $124(2)[65]$ & $81(1)[65]$ & $36(5)$ & $112(2)$ & $23.1(0.3)$ & $7.40(0.0)$ & $6.04(0.09)$ & $151(12)$ & $18(0.7)$ & $5.2(0.2)[74]$ & $1.4(0.1)[74]$ & $3.1(0.4)[74]$ \\
\hline & H $519(18)$ & 77 & $43(1)$ & $26.4(0.4)$ & $130(2)[65]$ & $84(1)[65]$ & $37(3)$ & $110(2)$ & $23.8(0.2)$ & $7.41(0.0)$ & $6.21(0.08)$ & $291(18)$ & $23(1.2)$ & $4.5(0.2)[71]$ & $0.6(0.1)[74]$ & $2.7(0.3)[71]$ \\
\hline & $p<0.001$ & & 0.11 & 0.32 & 0.06 & 0.05 & $0.31^{d}$ & 0.29 & 0.02 & 0.01 & 0.08 & $<0.001$ & 0.001 & $<0.001$ & $<0.001$ & 0.19 \\
\hline \multirow[t]{4}{*}{ D } & U-NIT & & & & & & & & & & & & & & & \\
\hline & L $85(3)$ & 59 & $43(1)$ & $26.4(0.3)$ & $126(3)[52]$ & $81(2)[52]$ & $38(5)$ & $109(3)$ & $23.0(0.3)$ & $7.40(0.0)$ & $6.13(0.10)$ & $184(16)$ & $19(1.0)$ & $5.0(0.2)[52]$ & $1.3(0.2)[52]$ & $3.5(0.4)[52]$ \\
\hline & H 184(11) & 58 & $42(1)$ & $26.5(0.3)$ & $127(3)[48]$ & $83(2)[48]$ & $35(4)$ & $115(3)$ & $23.4(0.2)$ & $7.40(0.0)$ & $6.20(0.10)$ & $278(22)$ & $22(1.3)$ & $4.5(0.2)[57]$ & $0.7(0.2)[57]$ & $2.3(0.4)[57]$ \\
\hline & $\mathrm{p}<0.001$ & & 0.43 & 0.41 & 0.39 & 0.26 & $0.31^{d}$ & 0.09 & 0.19 & 0.41 & 0.33 & $<0.001$ & 0.04 & 0.04 & 0.004 & 0.02 \\
\hline \multirow[t]{4}{*}{$\mathrm{E}$} & U-NIT/P-UA & & & & & & & & & & & & & & & \\
\hline & L $247(10)$ & 59 & $41(1)$ & $26.4(0.3)$ & $126(3)[54]$ & $81(2)[54]$ & $36(5)$ & $111(3)$ & $23.1(0.1)$ & $7.40(0.0)$ & $6.11(0.109$ & $184(16)$ & $19(0.9)$ & $5.0(0.2)[53]$ & $1.2(0.2)[53]$ & $3.2(0.4)[53]$ \\
\hline & H 533(35) & 58 & $44(1)$ & $26.5(0.4)$ & $127(3)[46]$ & $83(2)[46]$ & $37(5)$ & $113(3)$ & $23.3(0.2)$ & $7.40(0.0)$ & $6.23(0.10)$ & $278(22)$ & $21(1.3)$ & $4.4(0.2)[56]$ & $0.7(0.2)[56]$ & $2.5(0.4)[56]$ \\
\hline & $\mathrm{p}<0.001$ & & 0.13 & 0.42 & 0.42 & 0.22 & $0.34^{d}$ & 0.34 & 0.37 & 0.49 & 0.20 & $<0.001$ & 0.11 & 0.03 & 0.008 & 0.10 \\
\hline
\end{tabular}

*: Number of patients in strata; **: Creatinine clearance; $\mathrm{p}$ (in bold): level of significance $\leq 0.05 ;{ }^{\mathrm{d}}:$ based on $\log _{10}$ data; shaded areas: parameters supposedly participating in IRCU pathogenesis. 
Table 2b. Additional data (urine, plasma, urine/plasma) from the same IRCU patients as organized in Table 2a. Data are mean (SE).

For further informations see footnotes, Table $2 \mathrm{a}$ and text.

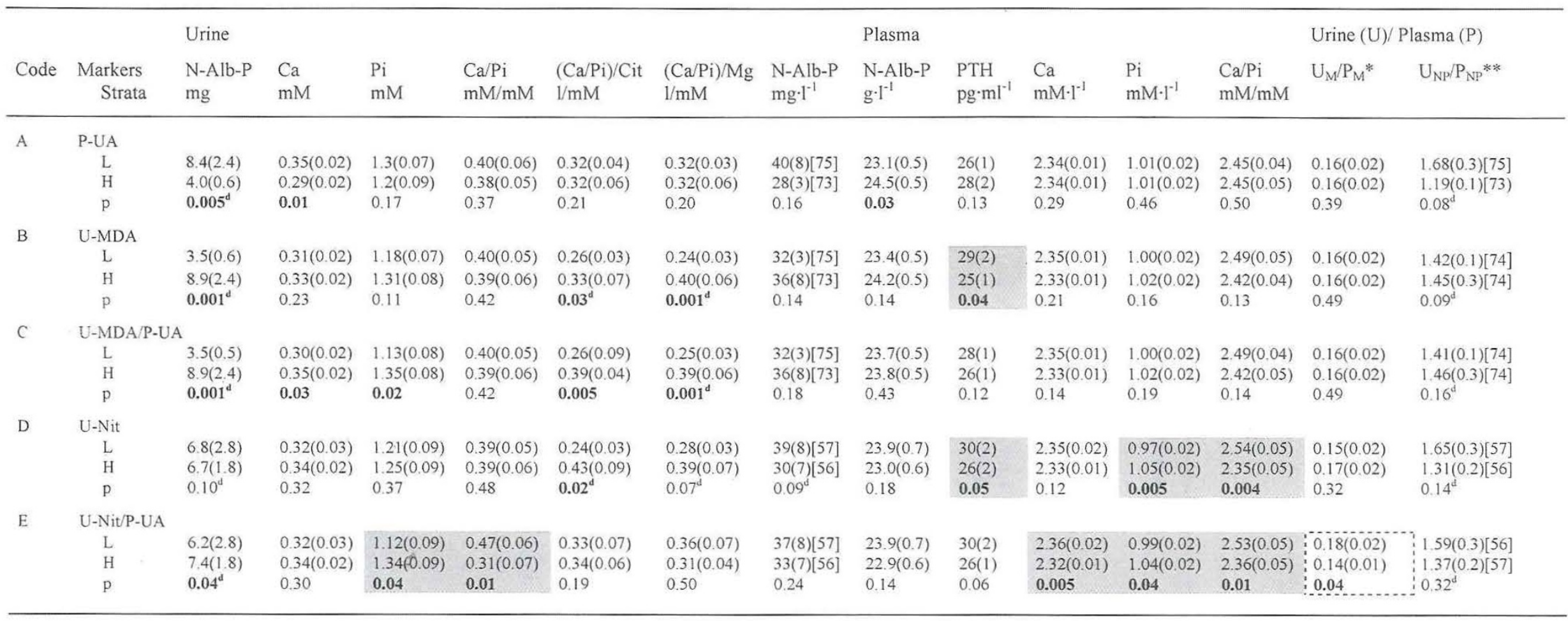

d: based on $\log _{10}$ data; $*$ : denotes $\mathrm{Ca} / \mathrm{Pi}$ in urine divided by $\mathrm{Ca} / \mathrm{Pi}$ in plasma; **: denotes $10^{3} \mathrm{x} \mathrm{N}-\mathrm{Alb}-\mathrm{P}$ in urine divided by $\mathrm{N}-\mathrm{Alb}-\mathrm{P}$ in plasma; dashed position $\left(\mathrm{U}_{\mathrm{M}} / \mathrm{P}_{\mathrm{M}}\right.$ ): end-point of $\mathrm{Ca}$ and $\mathrm{Pi}$ metabolism, as modified by change of parameters given as shaded positions (codes E, D, B). 

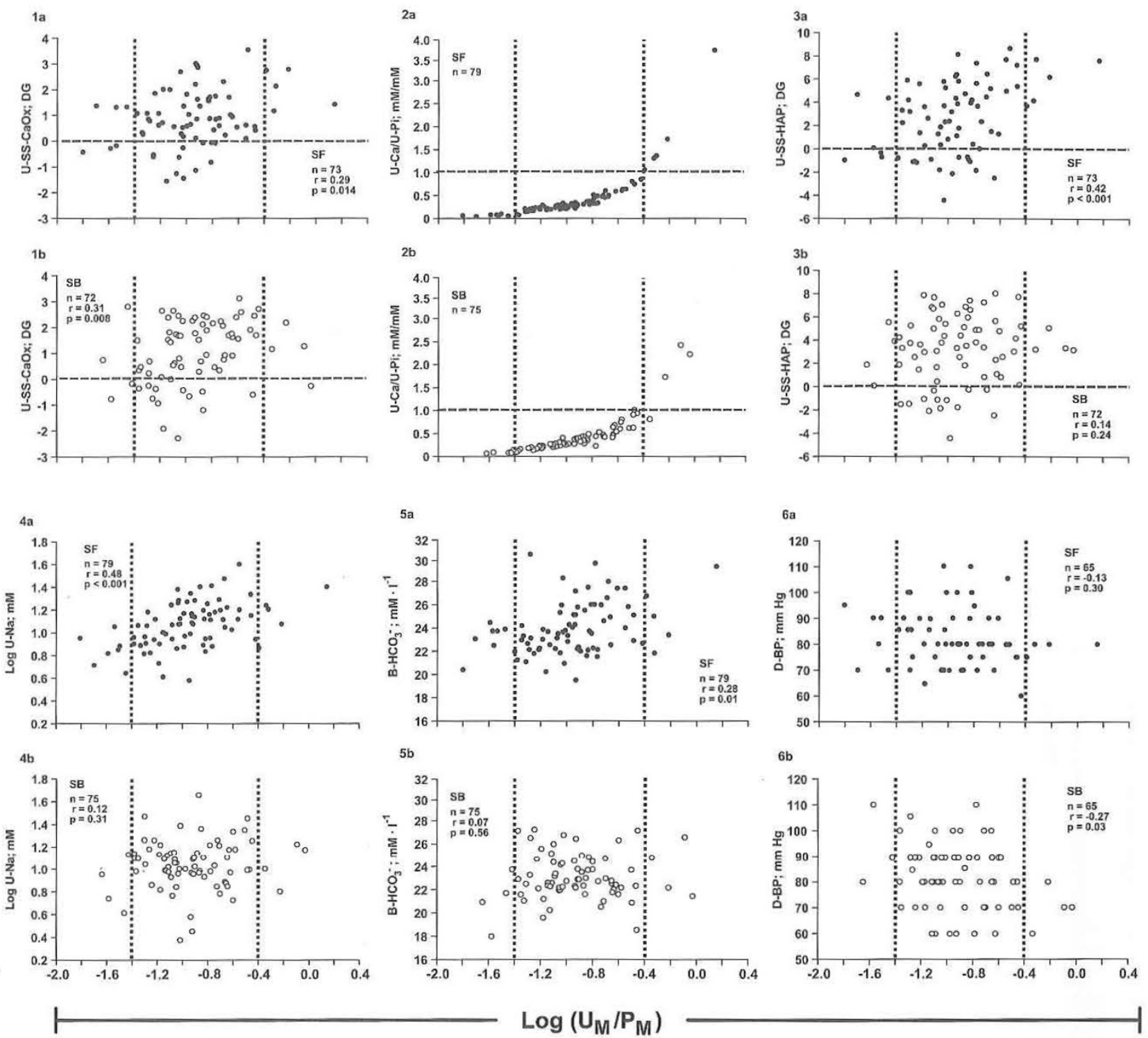

Fig. 2. Synopsis of variables linking $\mathrm{U}_{\mathrm{N}} / \mathrm{P}_{\mathrm{M}}$ (synonymous $\mathrm{Ca} / \mathrm{Pi}$ in urine divided by $\mathrm{Ca} / \mathrm{Pi}$ in plasma) to urine $\mathrm{U}-\mathrm{SS}-\mathrm{CaOx}$, $\mathrm{U}$ $\mathrm{Ca} / \mathrm{U}-\mathrm{Pi}, \mathrm{U}-\mathrm{SS}-\mathrm{HAP}, \mathrm{U}-\mathrm{Na}, \mathrm{B}-\mathrm{HCO}_{3}{ }^{-}$, D-BP in SF $(\bullet)$ and $\mathrm{SB}(\mathrm{O})$ patients, respectively. In the same order, except U-Ca/U-Pi, the partial regression coefficients in MRA (beta, followed by p-value) were: SF $0.33,0.003 ; 0.21,0.06 ; 0.51,<0.001 ; 0.11,0.27$; $0.04,0.71 ; \mathrm{SB} 0.35,0.009 ; 0.10,0.43 ; 0.22,0.09 ;-0.04,0.75 ; 0.24,0.05$ (see Table 4, block "Calcium", for outcome $\mathrm{U}_{\mathrm{M}} / \mathrm{P}_{\mathrm{M}}$ and influential variables $1,3,4,5,6)$.

Stippled vertical lines: span the range of $\log \left(\mathrm{U}_{\mathrm{N}} / \mathrm{P}_{\mathrm{M}}\right)$ within which the vast majority of patients clusters (see panel $\left.2 \mathrm{a}, 2 \mathrm{~b}\right)$. Dashed horizontal lines: In panel $2 \mathrm{a}, 2 \mathrm{~b}$ these indicate that at molarity of urine $\mathrm{Ca} / \mathrm{Pi} \leq 1.0$ the majority of patients is exposed to ab initio present nanosized amorphous and poorly crystallized CaPi [46]; note also that most SF and SB patients exhibit SS$\mathrm{CaOx}$ values in the low range of supersaturation, by definition meaning that preformed HAP-containing stone nidus (interstitial plaques) upon their protruding into tubular lumen preferably can be overgrown by amorphous $\mathrm{CaPi}$, then $\mathrm{CaOx}$, and only thereafter by HAP (see panels $2 \mathrm{a}, 2 \mathrm{~b}$ vs. $1 \mathrm{a}, 1 \mathrm{~b}$ and $3 \mathrm{a}, 3 \mathrm{~b}$ ) explaining why $\mathrm{CaOx}$ dominates as stone mineral $[6,84]$.

(for exceptions see column Remarks) and Fig. 2 (panels $2 \mathrm{a}, 2 \mathrm{~b}$ omitted from MRA), the degree of outcome prediction differed dramatically, depending on whether $\mathrm{SB}$ and SF subsets are considered, or unclassified (SF + SB) IRCU (see Table 4): In SB, the combined impact of P-PTH, U-NIT and BMI upon $\mathrm{P}_{\mathrm{M}}$ (synonymous P$\mathrm{Ca} / \mathrm{P}-\mathrm{Pi}$ ) was borderline only significant, whereas in $\mathrm{SF}$ the same variables predicted $\mathrm{P}_{\mathrm{M}}$ highly significantly; also in SB, but not SF, D-BP and P-UA were significantly modulated by several OM biomarkers and BMI, respectively; in sharp contrast, in $\mathrm{SF}$, but not $\mathrm{SB}$, the outcome U-pH was modulated by $\mathrm{FE}-\mathrm{K}, \mathrm{B}-\mathrm{HCO}_{3}^{-}$,
FE- $\mathrm{Na}$ and $\mathrm{U}-\mathrm{Na}$, the outcome $\mathrm{B}-\mathrm{HCO}_{3}{ }^{-}$by $\mathrm{U}-\mathrm{pH}$ and $\mathrm{U}_{\mathrm{N}}$; finally, in both $\mathrm{SF}$ and $\mathrm{SB} \mathrm{P}_{\mathrm{NP}}$ and $\mathrm{U}_{\mathrm{NP}} / \mathrm{P}_{\mathrm{NP}}$ were roughly equally modulated by 5 and 2 influential variables, respectively. Collectively, in SF $92 \%$ of the variation of U-pH, B- $\mathrm{HCO}_{3}{ }^{-}, \mathrm{P}_{\mathrm{NP}}, \mathrm{U}_{\mathrm{NP}} / \mathrm{P}_{\mathrm{NP}}, \mathrm{P}_{\mathrm{M}}$ can explain that the risk of formation of new stone(s) is suppressed, whereas in SB $69 \%$ of the variation of D-BP, P-UA, $\mathrm{P}_{\mathrm{NP}}$ and $\mathrm{U}_{\mathrm{NP}} / \mathrm{P}_{\mathrm{NP}}$ can explain the risk of new stone formation (Table 4). Of importance, differences in outcome modulation as described for SF and SB subsets would go undetected when unclassified IRCU $(\mathrm{SF}+\mathrm{SB})$ is studied (Table 4). 
Table 3. Ranking of frequency distribution of SF and SB patients upon stratification according to medians of parameters selected from Fig. 1, Tables 2a, 2b, Appendix II. U: urine, B: blood, P: plasma

\begin{tabular}{|c|c|c|c|c|c|c|}
\hline \multirow[t]{2}{*}{ Parameters $^{\mathrm{a}-1}$} & \multirow[t]{2}{*}{$\mathrm{N}^{+}$} & \multirow[t]{2}{*}{ LOW* } & SF & \multirow[t]{2}{*}{$\mathrm{HIGH}^{* * *}$} & \multicolumn{2}{|l|}{ SF } \\
\hline & & & SB & & SB & \\
\hline \multirow[t]{2}{*}{ U-pH ${ }^{a}$} & 154 & $5.42(0.07)^{\text {***** }}$ & 50 & 6.57 & 29 & $0.0007^{++}$ \\
\hline & & $5.48(0.07)$ & 27 & 6.77 & 48 & $0.0006^{++1}$ \\
\hline \multirow{2}{*}{$\mathrm{B}-\mathrm{HCO}_{3}{ }^{-\mathrm{b}}$} & 154 & $21.7(0.3)$ & 33 & $25.3(0.3)$ & 46 & 0.036 \\
\hline & & $21.9(0.2)$ & 44 & $24.9(0.2)$ & 31 & 0.026 \\
\hline \multirow[t]{2}{*}{$\mathrm{D}-\mathrm{BP}^{\mathrm{c}}$} & 130 & $75(0.9)$ & 34 & $91(2)$ & 31 & 0.052 \\
\hline & & $69(1.5)$ & 23 & $89(1)$ & 42 & 0.038 \\
\hline \multirow[t]{2}{*}{ P-UA ${ }^{d}$} & 154 & 307 (5) & 45 & $412(10)$ & 34 & 0.076 \\
\hline & & $307(7)$ & 32 & $403(6)$ & 43 & 0.053 \\
\hline \multirow[t]{2}{*}{ P-N-Alb-P } & 154 & $20.1(0.04)$ & 34 & $27.1(0.05)$ & 45 & 0.108 \\
\hline & & $20.1(0.04)$ & 42 & $27.7(0.05)$ & 33 & 0.074 \\
\hline \multirow[t]{2}{*}{ Log U-Volume $e^{f}$} & 154 & $2.0(0.02)$ & 34 & $2.49(0.03)$ & 45 & 0.108 \\
\hline & & $2.0(0.02)$ & 42 & $2.50(0.03)$ & 33 & 0.074 \\
\hline \multirow[t]{2}{*}{$\mathrm{U}-\mathrm{Na}^{\mathrm{g}}$} & 154 & $8.0(0.3)$ & 36 & $17.1(0.9)$ & 43 & 0.259 \\
\hline & & $8.2(0.4)$ & 41 & $17.3(1.2)$ & 34 & 0.167 \\
\hline \multirow[t]{2}{*}{ Log FE-UA ${ }^{h}$} & 154 & $0.78(0.01)$ & 36 & $0.99(0.01)$ & 43 & 0.259 \\
\hline & & $0.70(0.03)$ & 41 & $1.0(0.02)$ & 34 & 0.167 \\
\hline \multirow[t]{2}{*}{ Log U-N-Alb-P ${ }^{i}$} & 148 & $1.08(0.03)$ & 41 & $1.57(0.03)$ & 35 & 0.324 \\
\hline & & $1.14(0.03)$ & 33 & $1.66(0.05)$ & 39 & 0.074 \\
\hline \multirow[t]{2}{*}{$\log \mathrm{U}_{\mathrm{NP}} / \mathrm{P}_{\mathrm{NP}}{ }^{k}$} & 148 & $-0.30(0.03)$ & 41 & $0.21(0.03)$ & 35 & 0.413 \\
\hline & & $-0.24(0.03)$ & 34 & $0.33(0.05)$ & 38 & 0.257 \\
\hline \multirow[t]{2}{*}{$\log \left(\mathrm{U}_{\mathrm{M}} / \mathrm{P}_{\mathrm{M}}\right)^{1}$} & 154 & $-1.23(0.03)$ & 39 & $-0.69(0.04)$ & 40 & 0.865 \\
\hline & & $-1.19(0.03)$ & 36 & $-0.67(0.04)$ & 39 & 0.497 \\
\hline
\end{tabular}

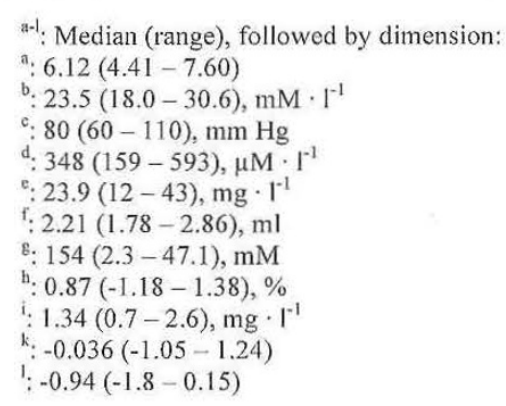

\section{COMMENTS}

Study design and strategy - Proposal of order of events Comparing subsets of IRCU, for example patients with hypercalciuria or normocalciuria with healthy controls, has a long tradition, but failed to clarify why stones form even in the absence of risk factors such as urinary excess of calcium (in the authors' laboratory $\mathrm{Ca}$ in daily urine is in the range of normals in approx. two thirds of patients (unpublished data)) and/or deficit of crystallization and stone inhibitors. On the other hand, in comparative controlled studies, signs of tissue inflammation such as elevated serum C-reactive protein (CRP) were found in overweight patients with unknown state of kidney stone formation [47], high CRP together with deficiency of antioxidant vitamins in IRCU as a whole (SF + SB) [48], elevated CRP in association with elevation of biomarkers of oxidative stress in patients with moderate kidney diseases [49]. Inflammatory protcins also are components of renal $\mathrm{CaOx}_{\text {[50] }}$ and other $\mathrm{Ca}$ crystal-containing stones [51], whereas in present work the moderate rise of U-NAlb-P (as putative but crude marker of proteins with inflammatory and other adverse functions) appears compatible with impact of stratum High of P-UA, UMDA/P-UA, U-NIT/P-UA (Table 2b, codes A-E). Apparently, rather than controlled studies those aimed at comparing IRCU subsets exhibiting so far largely neglected features (for example ROS regulation of protcin in terms of anatomic location, structure and function, minerals, BP) may set the stage for change of paradigms in pathogenesis of this disorder [8, 44-46], 


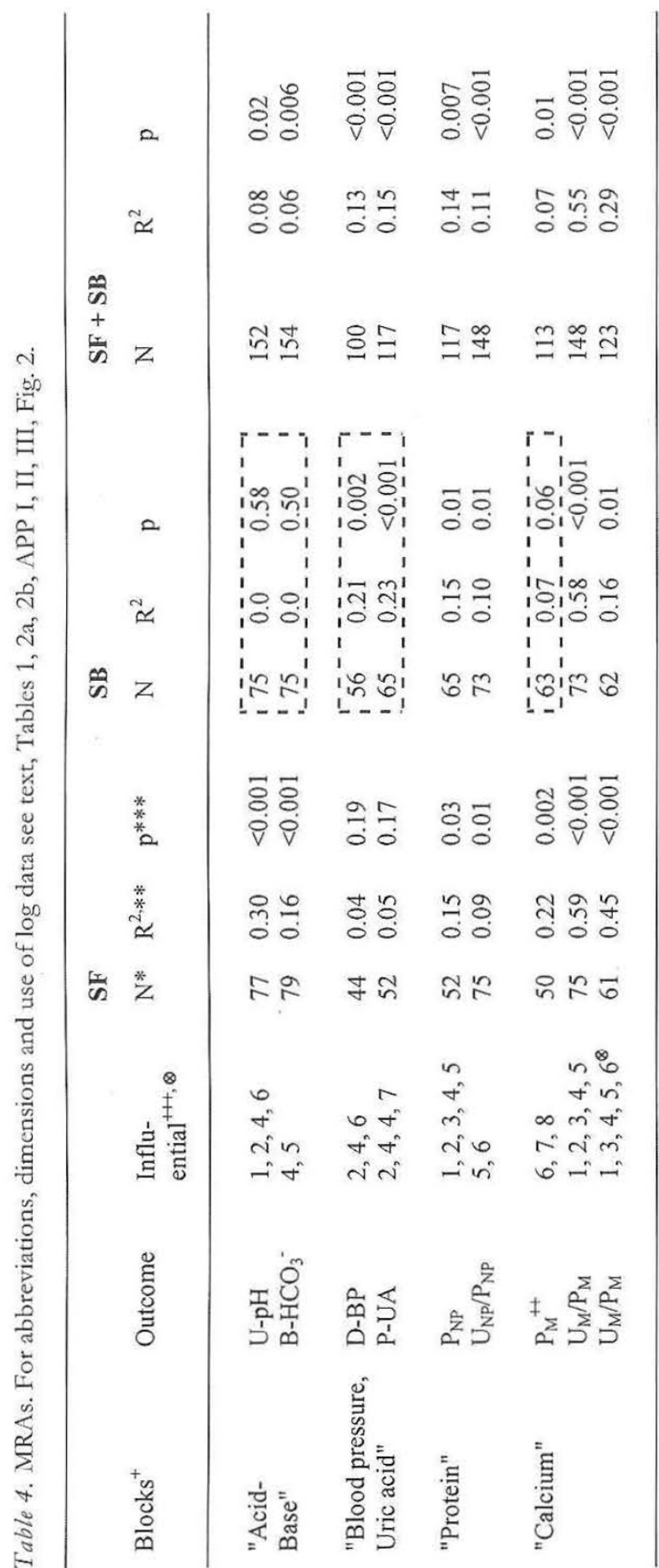

notwithstanding objections that so doing would leave unclarified those mechanisms underlying the numerous renal and systemic metabolic parameters associated with formation of first stone.

It has been proposed that oxidative stress combined with nitrative stress (see below) is a prominent feature also of chronic diseases other than IRCU [52]. In IRCU observations on pre-existence and site of origin of both kinds of stress and interactions to form stones are unknown up to now, whereas in calcification processes of blood vessels respective reports abound [35]. Earlier work described ischemia and microvascular diseases as causes of renal tubule-interstitial disease [53], identified ischemia and anoxia as abet- tor of renal tissue lipid peroxidation [54] and in the transplanted kidney as cause of alteration of renal cortical cation composition [55], as pre-decessor of oxidant/antioxidant imbalance together with glomerular and intracpithelial tubular $\mathrm{CaPi}$ deposition and $\mathrm{BP}$ elevation after infrarenal vascular grafting [56]; finally, repair processes of blood vessel tissue ("response to vascular injury") were accused as ROS source [57], and expanding adipose tissue surrounding blood vasculature has been identified as key player in hypoxia induction via static narrowing of vessel diameter [58], subsequent endothelial dysfunction [59], production of ROS [60] and inflammation [61]. Thus, ROS excess within kidney, together with opposite differentiation of vascular and bone cells by hydrogen peroxide [62] - a member of the ROS family of which the OM marker U-MDA (Table 2a, code B) is a descendant - may facilitate unforced events such as extracellular matrix vesicle calcification [63] via P-Ca and P-Pi dysregulation (Table 2b, code D) and mineral accumulation at appropriate ambient $\mathrm{P}-\mathrm{Ca} / \mathrm{P}-\mathrm{Pi}$ and $\mathrm{pH}$ [64]. Since SF and SB subsets are similarly overweight and $\mathrm{OM}$ biomarkers statistically indistinguishable (Table 1), it is not surprizing that plaques apparently arise in basolateral urothelial membranes, interstitial, perivascular and possibly vascular wall tissue $[5,6,9,45]$. In IRCU as a whole a decrease of bone mineral density has been known for long $[65,66]$; both, decrease of bone mineral formation and increase of bone mineral dissolution carry the risk of pouring extra Ca into blood circulation, in turn seeking dissipation via tubular fluid and urine or, in the more alkaline extra-luminal environment, deposition as $\mathrm{CaPi}$ in renal tissues. However, searching for more details of a ROS-mediated bone-kidney functional axis [67] in IRCU was beyond the scope of present work.

\section{ROS excess from bypoxia - Tractor for}

disturbances

Unless neutralized by antioxidants or treatment [68], hypoxia-derived ROS excess deteriorates cellular ultrastructure and function, regulation of endothelial function and vascular tone included [69, 70[. In present work indices of functional changes are tentatively marked by the "red line" that extends from alteration of blood acid-base, urine protein, Na, diuresis, BP, P-P'TH, to P-Ca and PPi status (see shaded areas in Tables $2 \mathrm{a}, 2 \mathrm{~b}$, APP I, II). Important questions arise, for example: Why is there failure of $\mathrm{U}-\mathrm{pH}$ to rise significantly upon exposure of kidney to high U-MDA and U-MDA/P-UA, why is there upregulation of $\mathrm{D}-\mathrm{BP}$ and $\mathrm{B}-\mathrm{HCO}_{3}{ }^{-}$with these MDA markers (Table $2 \mathrm{a}$, codes $\mathrm{B}, \mathrm{C}$ ) but not with isolated variation of P-UA (Table $2 \mathrm{a}$, code $\mathrm{A}$ ), and why are these phenomena restricted to SB patients (Table 4). More specifically: When the IRCU kidney is a target of ROS emanating from systemic hypoxia, is P-UA an 


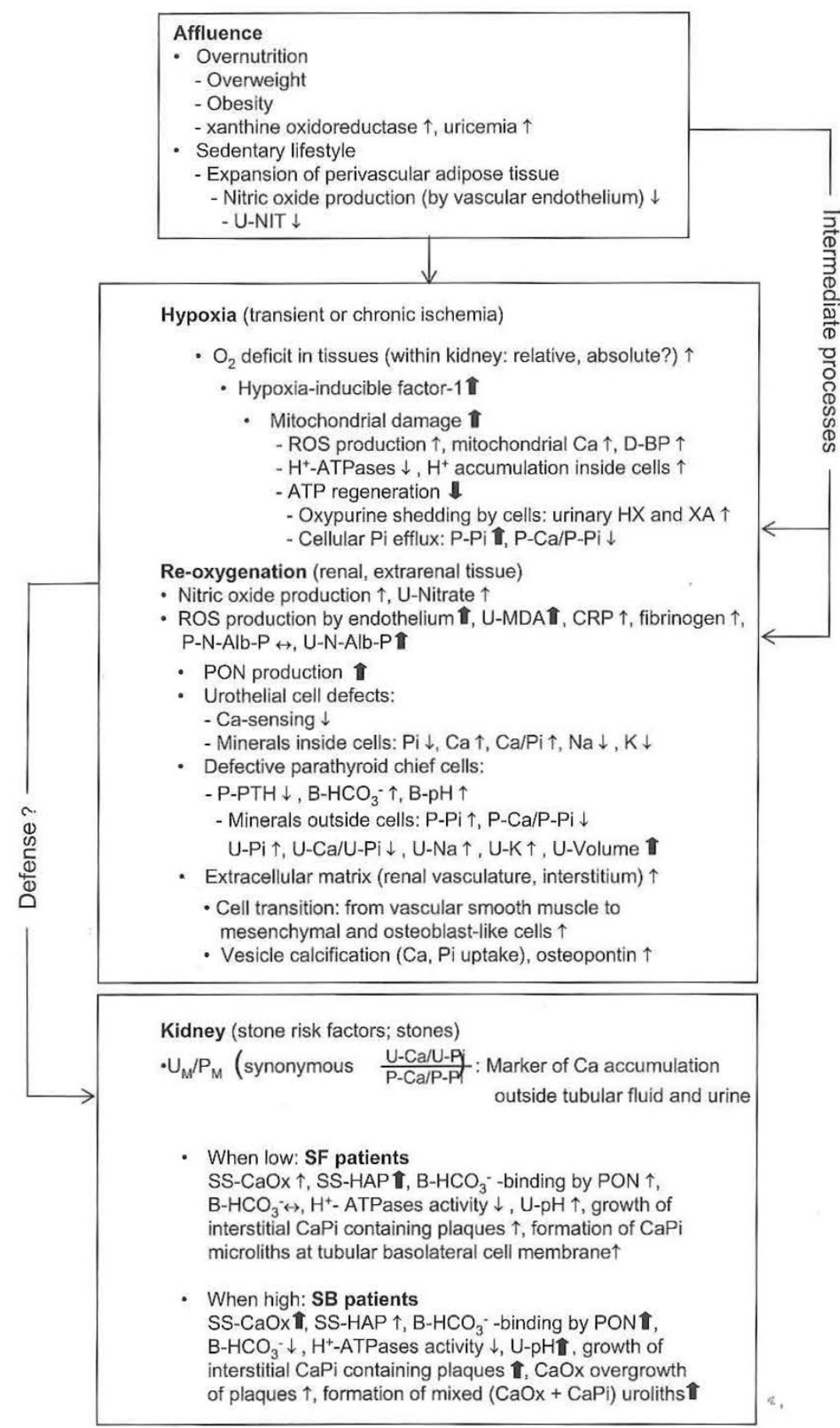

Fig. 3. Tentative flow scheme of events in IRCU, together facilitating malregulation of mineral, acid-base, BP and protein status, renal interstitial $\mathrm{CaPi}$ deposition (plaques) and Ca stone formation. BP: blood pressure; B: blood; P: plasma; U: urine; $\uparrow, \downarrow, \leftrightarrow$ : increase, decrease, no change, respectively; ?: Uncertain or unknown. For further abbreviations and information see text.

antioxidant [12[, oxidant [35], or bystander? Plausible explanations regarding these points are not available, but a number of telltale hints allow commenting: 1) In systemic metabolism, encompassing the presence of oxidants and antioxidants, the antioxidative tissue protecting actions of P-UA within physiological levels [12] may be simply overwhelmed by deleterious actions of ROS [71]; alternatively, primary ROS-mediated net renal loss of UA (APP II, FE-UA) may indicate that low
P-UA levels (relative to U-MDA) are consequence rather than cause of ROS. 2) From the positive correlation of urinary precursor oxypurines of UA synthesis (U-HX, U-XA) with U-pH in SF and SB subsets (APP III, block "Acid-Base"; position 8) defective mitochondrial nucleotide incorporation into cell-energizing ATP and fuelling of $\mathrm{H}^{+}$-ATPases may be inferred, a process that in renal tissue is extremely sensitive to hypoxia $[69,72,73]$; also, the anatomic organization of renal vasculature predisposes to damage of functionally highest developed medullary nephrons, after all once oxygen supply and metabolic demand are discordant [74]; luminal membrane $\mathrm{H}^{+}$-ATPase activity of ascending loop [75] may be especially susceptible to ROS attacks, while in some other tubular region enzyme activity can withstand. 3) Subsequent processes like $\mathrm{Ca}$ overload of mitochondria [76], release of hypoxia-inducible factor (HIF) [77] and other proteins (CRP, fibrinogen) [78] reflect hypoxia-induced interruption of mitochondrial electron transfer and generation of extra amounts of ROS [79]. 4) The significantly higher $\mathrm{D}-\mathrm{BP}$ in the SF vs. SB moiety (Table 3, parameter D-BP, stratum Low) would agree both with NO deficit as fundamental defect in chronic kidney disease [80] and ROS contribution to decreasing dilation and growing stiffness of arterioles (renal resistance arteries) [81], viz a process beginning with mitochondrial dysfunction [73] that progresses to vascular tone adaption [79], hypertension [81], $\mathrm{Ca}$ accumulation and $\mathrm{CaPi}$ deposition inside vessel walls [82]. 5) Observations that P-UA itself is an oxidant and harbinger of ischemic tissue injury [83] cannot be reconciled with the insignificant simple correlation of P-UA and D-BP in SB subset (APP III, block "Blood pressure, Uric acid", position 5), and the highly significant direct correlations of P-UA and D-BP with BMI in SB and SF (APP III, "Blood pressure, Uric acid", positions 6, 7) point towards BMI as a major environmental effector of P-UA and D-BP levels (see also Fig. 3). 6) Contrasting with SF, in SB the negative correlations of U-NIT/P-UA with PTH, of U-NIT with PTH, and of U-NIT with $\mathrm{P}_{\mathrm{M}}$ (APP III, block "Calcium", positions $11,10,7)$ may be token that NO deficiency [80] or, alternatively, loss of function principle of NO (nitrative stress; see below), has additional ramifications into regulation of P-Ca and P-Pi (synonymous $\mathrm{P}_{\mathrm{M}}$ ). Should these interpretations be confirmed, then the ROS-damaged but still stone-free 
IRCU kidney first increases the risk for BP clevation (APP III, block "Blood pressure, Uric acid", position $3)$ and then the formation risk of new stone on the basis of $\mathrm{P}_{\mathrm{M}}$ modulation by low U-NIT (APP III, block "Calcium", position 7)

\section{$P_{M}$-Integral of ROS-initiated cellular defects?}

In $\mathrm{Ca}$ stones the dominant component is $\mathrm{CaOx}$, although in smaller stones $(<20 \mathrm{mg})$ the core is $\mathrm{CaPi}$ [84]. However, whether along the nephron and at which site intratubular U-SS-CaOx dominates over USS-HAP and vice versa is an ongoing matter of controversy [85]. The impressive curvilinear linkage of $\mathrm{U}_{\mathrm{M}} / \mathrm{P}_{\mathrm{M}}$ to $\mathrm{U}_{\mathrm{M}}$ (Fig. 2, panels $2 \mathrm{a}$ and $2 \mathrm{~b}$ ), a so far unreported phenomenon in IRCU, testifies that a rise of $\mathrm{U}_{\mathrm{M}}$ (synonymous U-Ca/U-Pi) above 1.0 is limited by growing $\mathrm{P}_{\mathrm{M}}$; accordingly, U-Volume-independent precipitation of amorphous CaPi [7] should be detectable in most patients, leaving the possibility that due to U$\mathrm{Ca}$ excess in a minority of patients $\mathrm{CaPi}$ phases such as Ca-Hydrogen-Phosphate (Brushite; crystallization starts at $\mathrm{Ca} / \mathrm{Pi}=1.0)$ can develop and promote the transformation to HAP as well as heterogeneous $\mathrm{CaOx}$ nucleation by HAP (and its less $\mathrm{Ca}$ containing precursors (for more details see ref. [85, 86, 87]). In fact, in fasting urine of IRCU males only non-crystallized $\mathrm{CaPi}$ ("isotropic" by petrographic microscopy) particles abound, whereas $\mathrm{CaOx}$ crystals are the exception [21]. In addition, the failure of increasing SS of both Ca salts to manifest as shift from SF to SB patients ( $p>0.10$, see Table 3), despite high U-Volumemediated low inhibitor concentration (APP III, block "Calcium", positions 1,2), argues for an alternative scenario of formation of new stone(s): it should include initial tissue damage by ROS (as shown herein), followed by deterioration of function of the axis tubular luminal membrane Ca receptors [88] $\rightarrow$ parathyroid gland activity $\rightarrow \mathrm{U}-\mathrm{Ca} / \mathrm{U}-\mathrm{Pi}$ (synonymous $\mathrm{U}_{\mathrm{M}}$ ), with the consequences that in this setting decrease of PPTH (Table 2b, code B), increase of P-Pi, and decrease of P-Ca/P-Pi (Table $2 \mathrm{~b}$, codes D, E) emerge as central events. This interpretation would be in agreement with vascular smooth muscle cell adaption and release of calcifying vesicles in response to dysregulation of ambient $\mathrm{Pi}$ and $\mathrm{Ca}[63,89]$, and the positive (in healthy normals negative, according to textbooks) correlation of $\mathrm{P}_{\mathrm{M}}$ with $\mathrm{PTH}$, as seen in SF under conditions of high U-NIT, hence high endothelial NO production (APP III, block "Calcium", position 6). Not surprisingly therefore, in present work U-NIT and UMDA are directly correlated $(\mathrm{n}=52, \mathrm{r}=0.49, \mathrm{p}$ $<0.001$, and $\mathrm{n}=65, \mathrm{r}=0.25, \mathrm{p}=0.05$, for SF and SB, respectively), suggesting that once high U-MDA (ROS excess; Table $2 \mathrm{a}$, code $\mathrm{B}$ ) meets high U-NIT (high NO production; Table $2 \mathrm{a}$, code $\mathrm{D}$ ) then peroxynitrate $(\mathrm{PON})$ is formed [34]; this reaction product of superoxide anion (the precursor of hydrogen peroxide) with NO-derived nitrite and nitrate $[33,34,35]$ is highly toxic to constituents of living cells especially of vascular endothelium [90], can be reconciled with downregulation of PTH in presence of high U-MDA and UNIT (Table 2b, codes B and D) and, from reasons outlined below, with declining $\mathrm{B}-\mathrm{HCO}_{3}^{-}$as strong $\mathrm{Ca}$ stone formation driving force (Table 3).
Ca stones in situ - Endpoint of one paradox or several?

Irrespective of whether in a given stone $\mathrm{CaPi}$ or $\mathrm{CaOx}$ is the dominant mineral, the organic stone matrix contains a myriad of especially inflammatory proteins $[50$, 51] and osteopontin, a phosphorylated multifunctional protein [91], almost all renal stones are found attached to preformed plaques [92], plaque apatite and osteopontin are co-localized [93], and mice lacking osteopontin develop $\mathrm{CaPi}$ crystals and stones in renal papillae [94]. Surprisingly, neither are components of the plaques' [4]organic matrix known, nor do $\mathrm{U}_{\mathrm{N}} / \mathrm{P}_{\mathrm{M}}$ and $\mathrm{U}_{\mathrm{NP}} / \mathrm{P}_{\mathrm{NP}}$ in present work reflect that the kidney shifts from SF to SB state (Table 3). Despite, a rather crude gauge for a bridging role of protein(s) between plaques and stones may be seen in correlations of present work: Although in both SF and SB patients the degree of variation of $\mathrm{P}_{\mathrm{NP}}$ as outcome is similar and significantly predicted (Table 4; block "Protein"), in SF the impact of U-MDA upon $\mathrm{P}_{\mathrm{NP}}$ is insignificantly negative, in SB significantly positive (APP III, block "Protein", position 2); this hitherto unreported paradox suggests that in SB P-NP members are indeed ROSmodified with respect to structure, function and possibly concentration, and therefore distinct from those in SF. Thus, a realistic speculation would be that like in vascular tissue also in plaques of IRCU osteopontin as modified by oxidation [95] or loss of phosphorylation [96] is present and able to fill the gap between vascular and perivascular interstitium, peritubular space and urothelium, thereby disguising its origin from blood vasculature. Once this type of plaques protrudes into tubular lumen, it may serve as nidus for stone formation $[6,85]$. Closer insight into upregulation of U-Volume (Table 2a) is hampered by the inconsistent changes of plasma osmolarity and AVP in response to OM biomarker variation (APP I): From positive correlation of U-Volume with $\mathrm{U}-\mathrm{Na}$, viz assumed loss of body fluid due to rise of U-Na (APP III, block "AcidBase", position 6) via prior cell membrane damage and protein shedding into urine (Table $2 \mathrm{~b}$, code $\mathrm{B}$ ), one would expect positive correlation of U-Volume and $\mathrm{U}_{\mathrm{NP}} / \mathrm{P}_{\mathrm{NP}}$; however, in both $\mathrm{SF}$ and $\mathrm{SB}$ this correlation is negative (APP III, block "Protein", position 6), leaving the possibility that impaired transport of water is due to initial ROS modulation of trans-membrane $\mathrm{Na}$ or/and water channels [97]. Finally, the drive toward stone formation in the presence of declining B$\mathrm{HCO}_{3}^{-}$(Table 3) but absence of systemic metabolic acidosis (in normals $\mathrm{B}-\mathrm{pH}$ is $7.35-7.45, \mathrm{~B}_{-} \mathrm{HCO}_{3}{ }^{-} 18$ $-30 \mathrm{mM} \cdot 1-1)$ is interpreted as follows: The equilibrium between $\mathrm{B}-\mathrm{HCO}_{3}{ }^{-}$and $\mathrm{CO}_{2}$ as dissolved in plasma functions as important buffer, with $\mathrm{HCO}_{3}^{-}$being increasingly bound by PON [13], thereby detracting from $\mathrm{B}-\mathrm{HCO}_{3}{ }^{-}$levels; the chemistry of PON is complex [13], but the reaction may be facilitated during reoxygenation of previously hypoxic tissue, a situation with the mentioned high production rates of $\mathrm{NO}$ and ROS [34]. Since the power of PON to oxidize cell membrane proteins and lipids, and numerous other substances, DNA included, is enormous [13, 34, 98], maintenance of normal circadian rhythm of plasma $\mathrm{NO}$ and physiological levels of P-UA (acting as PON scavenger in this setting) has been proposed [99]. Collectively, IRCU pathogenesis in the absence of urinary 
Ca salt SS as stone formation driving force (this work) proves elusive, meaning that decipherment of factors such as oxidative and nitrative stress in signalling network ("Crosstalk between cells") may be key for elucidation at the cellular and molecular level [100]; in this respect IRCU would resemble calcification of blood vasculature $[63,101]$ and other widespread human diseases $[102,103]$.

\section{CONCLUSions}

The present IRCU study, organized in a "bringing the bedside to the bench" manner, substantiates that, depending on the state of selected OM biomarkers, a number of Ca stone related parameters of blood, plasma and urine are paradoxically disordered: During eubicarbonatemia (absence of overt metabolic acidosis) $\mathrm{B}-\mathrm{HCO}_{3}{ }^{-}$and $\mathrm{D}-\mathrm{BP}$ rise in association with rise of the lipid-peroxidation markers U-MDA and U-MDA relative to P-UA, whereas $\mathrm{U}_{\mathrm{M}}, \mathrm{P}_{\mathrm{N}}, \mathrm{U}_{\mathrm{N}} / \mathrm{P}_{\mathrm{M}}$ and P-PTH decrease in association with rise of the NO-derived markers U-NIT and U-NIT relative to P-UA. Stone neoformation appears mainly driven by interaction of oxidative (high U-MDA and U-MDA/P-UA) and nitrative (high U-NIT and U-NIT/P-UA) stress, presumably leading to lowering of $\mathrm{B}-\mathrm{HCO}_{3}{ }^{-}$via binding to a so far neglected metabolic intermediate. Although observed data need confirmation by controlled studies, a tentative view of events (Fig. 3) gives the impression that IRCU is best conceived as a defense process against affluent lifestyle-introduced consequences for renal tissues, blood and urine constituents. Further intense research into mechanisms underlying OM-modulation of acid-base status, mineral and protein homeostasis, and dynamics of blood vasculature is justified.

Acknowledgements: We are grateful to numerous practicing physicians for long-year cooperation with patients, our coworkers Karin Schwille for technical, Marie-Luise Rasenack for secretarial assistance. Financial support was granted by the University of Erlangen Hospital Research Funds and the Deutsche Forschungsgemeinschaft Bonn/Berlin, Germany.

\section{REFERENCES}

1. Finlayson B, Khan SR, Hackett RL. Theoretical chemical models of urinary stones. In: Renal Tract Stone, Metabolic Basis and Clinical Practice; Wickham JEA, Buck AC (eds). Churchill Livingstone, Edinburgh, London, Melbourne, New York, 1990:133-47.

2. Robertson WG, Peacock M, Marshall RIW, Marshall DH, Nordin BEC. Saturation-Inhibition index as a measure of the risk of calcium oxalate stone formation in the urinary tract. N. Engl J Med 1976;294:249-52

3. Kok DJ, Khan SR. Calcium oxalate nephrolithiasis, a frec or fixed particle disease. Kidney Int 1994;46:847-54.

4. Randall A. The origin and growth of renal calculi. Ann Surg 1937;105:1009-1027.

5. Anderson CK. Renal histological changes in stone formers and non-stone formers. In: Renal Stone Rescarch Symposium; Hodgkinson A, Nordin BEC (eds). JA Churchill, London, 1969;133-6.

6. Evan AP, Lingeman JE, Coe FL, Worcester EM. Role of interstitial apatite plaque in the pathogenesis of the common calcium oxalate stone. Semin Nephrol 2008;28:111-9.

7. Cheng PTI, Pritzker KPH. Solution $\mathrm{Ca} / \mathrm{P}$ ratio affects calcium phosphate crystal phases. Calcif Tiss Int 1983;35:596601.
8. Halpcrin MI, Cheema Dhadli S, Kamel SK. Physiology of acid-base balance: links with kidney stone prevention. Semin Nephrol 2006;26:441-6.

9. Stoller ML, Low RK, Shami GS. McCormick VD, Kerschmann RL. High resolution radiography of cadaveric kidneys: unraveling the mystery of Randall's plaque formation. J Urol 1996;156:1263-6.

10. Schwille PO, Rümenapf $G$. Idiopathic calcium urolithiasis Clinical problems and suggested approaches in an ambulatory stone clinic. In: Renal Tract Stone, Metabolic Basis and Clinical Practice; Wickham JEA, Buck A (eds). Churchill Livingstone, Edinburgh, London, Melbourne, New York, 1990 pp 217-38.

11. Manoharan M, Schwille PO. Oxypurines, protein, glucose and the functional state of blood vasculature are markers of renal calcium stone-forming processes? Observations in men with idiopathic recurrent calcium urolithiasis. Clin Chem Lab Med 2002;40:266-77.

12. Becker BF. Towards the physiological function of uric acid Free Radic Biol Med 1993;14:615-31.

13. Whiteman M, Ketsawatsakul U, Halliwell B. A reassessment of the peroxynitrite scavenging activity of uric acid Ann N Y Acad Sci 2002;962:242-59.

14. Touyz RM. Reactive oxygen species as mediators of calcium signaling by angiotensin II: implications in vascular physiology and pathophysiology. Antiox Signal 2005;7: 1302-14.

15. Yung LM, Leung FP, Yao X, Chen ZY, Huang Y. Reactive oxygen species in vascular wall. Cardiovase Hematol Disord Drug Targets 2006;6:1-19.

16. Schmiedl A, Schwille PO. Is magnesium a marker of disordered mineral metabolism in males with idiopathic recurrent calcium urolithiasis? Observations focussing on fasting magnesiuria and magnesicmia, protein and other substances in urine and plasma. Magnesium Res 2003;16:192-205.

17. Schwille PO, Schmiedl A, Manoharan M. Is calcium oxalate nucleation in postprandial urine of males with idiopathic recurrent calcium urolithiasis related to calcium phosphate nucleation and the intensity of stone formation? Studics allowing insight into a possible role of urinary free citrate and protein. Clin Chem Lab Med 2004;42:283-93.

18. Schwille PO, Manoharan M, Schmiedl A. Is idiopathic recurrent urolithiasis in male a cellular disease? Laboratory findings in plasma, urine and erythrocytes, emphasizing the absence and presence of stones, oxidative and mineral metabolism: an observational study. Clin Chem Lab Med 2005;53:590-600

19. Schwille PO, Wipplinger J. Idiopathic recurrent calcium urolithiasis (IRCU): An acid meal uncovers inappropriate $\mathrm{pH}$ of postprandial, fasting and daily urine. A cross-sectional study of male patients providing insight into post- and pre-load urinary stone substances, crystallization risk, presence of renal stones, renal transport and svstemic metabolic factốrs. Eur J Med Res 2008;23:332-42.

20. Schwille PO, Schmiedl A, Wipplinger J. Idiopathic recurrent calcium urolithiasis (IRCU): Variation of fasting urinary protein is a window to pathophysiology or simple consequence of renal stones in situ? A tripartite study in male patients providing insight into oxidative metabolism as possible driving force towards alteration of urine composition, calcium salt crystallization and stone formation. Eur J Med Res 2009;14:378-92.

21. Hermann U, Schwille PO. Crystalluria in idiopathic recurrent calcium urolithiasis. Dependence on stone composition. Urol Res 1992;20:157-64.

22. Glantzounis GK, Tsimoyiannis EC, Kappas AM, Galaris DA. Uric acid and oxidative stress. Curr Pharm Des 2005;11:4145-51.

23. Mazzali M, Hughes J, Kim YG, Jefferson JA, Kang DH, Gordon KI, Lan HY, Kivlighn S, Johnson RJ. Elevated uric acid increases blood pressure in the rat by a novel crystal- independent mechanism. Hypertension 2001;38: 1101-6. 
24. Corry DB, Eslami P, Yamamoto K, Nyby MD, Mackino H, Tuck ML. Uric acid stimulates vascular smooth muscle cell proliferation and oxidative stress via the renin-angiotensin system. J Hypertension 2008;26:269-75.

25. Linder N, Rapola J, Raivio KO. Cellular expression of xanthine oxidoreductase protein in normal human tissues. Lab Invest 1999;79:967-74.

26. Hewinson J, Stevens CR, Miller TM. Vascular physiology and pathology of circulating xanthine oxidoreductase: from nucleotide sequence to functional enzyme. Redox Rep 2004; 9:71-9.

27. Enomoto A, Kimura H, Chairoungdua A, Shigeta $Y$, Jutabha $\mathrm{P}$, Cha SH, Hosoyamada M, Takeda M, Sekine T, Igarashi T, Matsuo H, Kikuchi Y, Oda T, Ichida K, Hosoya T, Shimokata K, Niwa T, Kanai Y, Endou H. Molecular identification of a renal urate anion exchanger that regulates blood urate levels. Nature 2002;417:447-52.

28. Esterbauer H. The chemistry of oxidation of lipoproteins. In: Oxidative Stress, Lipoproteins and Cardiovascular Dysfunction; Rice-Evans C, Bruckdorfer KR (eds). Portland Press Ltd, London, 1995, pp 55-79.

29. Stark G. Functional consequences of oxidative membrane damage. J Membr Biol 2005;205:1-16.

30. Furchgott RF, Zawadzki JV. The obligatory role of endothelial cells in the relaxation of arterial smooth muscle by acetylcholine. Nature 1980;288:373-6.

31. Tsikas D. Methods of qualitative analysis of nitric oxide metabolites nitrite and nitrate in human biological fluids. Free Radic Res 2005;39:797-815.

32. Jobgen WS, Jobgen SC, Li H, Meininger CJ, Wu G. Analysis of nitrite and nitrate in biological samples using highperformance liquid chromatography. J Chromatogr B Analyt Technol Biomed Life Sci 2007;851:71-82.

33. Darley-Usmar V, Hogg N. Kalyanaraman B, Moore K. Free radicals in the vasculature: pathological and physiological significance. In: Oxidative Stress Lipoproteins and Cardiovascular Dysfunction; Rice-Evans C, Bruckdorfer KR (cds). Portland Press Ltd, London, 1995, pp 81-98.

34. Estevez AG, Jordan J. Nitric oxide and superoxide, a deadly cocktail. NY Acad Sci 2002;962:207-11.

35. Vanhoutte PM. Endothelium-derived free radicals: For worth and for better. J Clin Invest. 2001;107:23-5

36. Manoharan M, Schwille PO. Measurement of oxalate in human plasma ultra filtrate by ion chromatography. J Chrom B 1997;700:261-8.

37 Carbonneau MA, Peuchant E, Sess D, Canioni P, Clerc M. Free and bound malonedialdehyde measured as thiobarbituric acid adduct by HPLC in serum and plasma. Clin Chem 1991;37:1423-9.

38. Everett SA, Dennis MF, Tozer GM, Prise VE, Wardman P, Stratford MRL. Nitric oxide in biological fluids: analysis of nitrite and nitrate by high performance ion chromatography. J Chromatogr A 1995;706:437-42.

39. Harkness RA. Hypoxanthine, xanthine and uridine in body fluids, indicators of ATP depletion. J Chromatogr 1988;429:255-78

40. Harkness RA, Saugstad OD. The importance of ATP depletion and subsequent cell damage with an estimate of size and nature of the market for a practicable method: a review for designed technology transfer. Scand J Clin Lab Invest 1997;57:655-72.

41. Werness PG, Brown CM, Smith LH. EQUIL-2: a BASIC computer program for the calculation of urinary saturation. J Urol 1985;134:1242-4.

42. Asplin JR. Obesity and urolithiasis. Adv Chronic Kidney Dis 2009;16:11-20.

43. Obligado SH, Goldfarb DS. The association of nephrolithiasis with hypertension and obesity. Am J Hypertens 2008;21:257-64.

44. Gambaro G, D'Angelo A, Fabris A, Tosetto E, Anglani F, Lupo A. Crystals, Randall's plaques and renal stones: do bone and atherosclerosis teach us something? J Nephrol 2004;17:774-7.
45. Coe FL, Evan AP, Lingeman JE, Worcester EM. Plaques and deposits in nine human stone diseases. Urol Res 2010;38:239-47.

46. Nancollas HG, Henneman ZJ. Calcium oxalate: Calcium phosphate ttansformations. Urol Res 2010;38:277-80.

47. Visser M, Bouter LM, McQuillan GM, Wener MH, Harris TB. Elevated C-reactive protein levels in overweight and obese adults. JAMA 1999;282:2131-5.

48. Manoharan M, Schwille PO, Schmiedl A. Are plasma and red blood cell (RBC) levels of antioxidative vitamins and uric acid disordered in idiopathic calcium urolithiasis (ICU)? A prelimary report. In: Urolithiasis 2000; Rodgers AI, Hibbert BE, Hess B, Khan SR, Preminger GM (eds). University of Cape Town, 2000, 547-9.

49. Oberg BP, McMenamin E, Lucas FL, McMonagh E, Morrow J, Ikizlar TA, Himmelfarb J. Increased prevalence of oxidant stress and inflammation in patients with moderate to severe kidney disease. Kidney Int 2004;65:1009-16.

50. Merchant ML, Cummins T, Wilkey DW, Salyer SA, Powell DW, Klein J13, Lederer ED. Proteomic analysis of renal calculi indicates an important role for inflammatory processes in calcium stone formation. Am J Physiol Renal Physiol 2008;295:F1254-F1258.

51. Canales BK, Anderson I, Higgins L, Ensrud-Bowlin K, Roberts KP, Wu B, Kim IW, Monga M. Proteome of human calcium kidney stones. Urology 2010, Oct; 76(4):1017 e13-20. Epub 2010 Aug 14.

52. Halliwell B. Hypothesis: Proteosomal dysfunction. A primary event in neurogeneration that leads to nitrative and oxidative stress and subsequent cell death. Ann NY Acad Sci 2002;962:182-94.

53. Nakagawa I, Kang OH, Ohashi R, Suga S, Herrera-Acosta J, Rodriguez-Iturbe B, Johnson RJ. Tubular-interstitial disease: role of ischemia and microvascular disease. Curr $\mathrm{Op}$ Nephrol Hypertens 2003;12:233-41.

54. Eschwege T, Paradis V, Conti M, Holstege A, Richet F, Detève $J$, Ménager $P$, Legrand $A$, Jardin A, Bedossa $P$, Benoit G. In situ detection of lipid peroxidation byproducts as markers of renal ischemia injuries in rat kidney. J Urol 1999;162:553-7.

55. Sells RA, McLoughlin GA, Tyrell I. Renal cortical cation composition as an index of kidney graft viability (abstract). Br J Surg 1974;61:326.

56. Schmiedl A, Schwille PO, Bonucci E, Seitz T, Schwille RM, Manoharan M. Renal cortical calcification in syngeneic intact rats and those receiving an infrarenal thoracic aortic graft: possible etiological roles of endothelin nitrate and minerals, and different preventive effects of long-term oral treatment with magnesium, citrate and alkali-containing preparations. Urol Res 2001;29:229-37.

57. Azevedo LCP, Pedro MDA, Souza LC, Souza HPD, Janiszwesky M, Luz PLD, Laurindo FRM. Oxidative stress as a signaling mechanism of the vascular response to injury: The redox hypothesis of restenosis. Cardiovasc Res 2000; 47:436-45.

58. Trayhurn P, Wang B, Wood IS. Hypoxia and the endocrine and signaling role of white adipose tissue. Arch Physiol Biochem 2008;114:267-76.

59. Rutkowski JM, Davis KE, Scherer PE. Mechanisms of obesity and related pathologies: the macro- and microcirculation of adipose tissue. FEBS J 2009;276:5738-46.

60. Greenstein AS, Khavandi K, Withers SB, Sonoyama K, Clancy O, Jeziorska M, Lainy I, Yates AP, Pemberton PW, Malik RA, Heagerty AM. Local inflammation and hypoxia abolish the protective anticontractile properties of perivascular fat in obese patients. Circulation 2009;119:166170.

61. Trayhurn P, Wood IS. Adipokines: inflammation and the pleiotropic role of white adipose tissuc. $\mathrm{Br} \mathrm{J}$ Nutr 2004;92:347-55.

62. Mody N, Parhami F, Sarafian TA, Demer LI. Oxidative stress modulates osteoblastic differentiation of vascular and bone cclls. Free Radic Biol Med 2001;31:509-19. 
63. Shroff RC, McNair R, Skepper JN, Figg N, Schurgers LJ, Deanfield J, Rees L, Shanahan CM. Chronic mineral dysregulation promotes vascular smooth muscle cell adaption and extracellular matrix calcification. J Am Soc Nephrol 2010;21:103-12.

64. Valhmu IWB, Wu LN, Wuthier RB. Effects of $\mathrm{Ca} /$ Pi ratio, $\mathrm{Ca}^{2+} \mathrm{xPi}$ ion product, and $\mathrm{pH}$ of incubation fluid on accumulation of ${ }^{45} \mathrm{Ca}^{2+}$ by matrix vesicles in vitro. Bone Miner 1990;8:195-209.

65. Barkin J, Wilson DR, Arief Manuel M, Bayley A, Murray T, Harrison J. Bone mineral content in idiopathic calcium nephrolithiasis. Min Electrol Metab 1985;11:19-24.

66. Ghazali A, Bataille P, Solal MC, Marié A, Brazier M, Seberth JL, Prin L, Fournier $A$. Bone involvement in idiopathic calcium lithiasis. Nephrologie 1995;16:351-69.

67. Fukagawa M, Hamada Y, Nakanishi S, Tanaka M. The kidney and bone metabolism: nephrologists' point of view. J Bone Miner Metab 2006;24:434-8.

68. Chaudry IH. Use of ATP following shock and ischemia. Ann NY Acad Sci 1990;603:130-40.

69. Chaudry IH. Cellular mechanisms in shock and ischemia and their correction. Am J Physiol 1983;245:R117-R134.

70. Michiels C, Arnoud T, Remacle J. Endothelial cell responses to hypoxia: initiation of a cascade of cellular events. Biochim Biophys Acta 2000;1497:1-10.

71. Freeman BA, Crap JD. Biology of disease. Free radicals and tissue injury. Lab Invest 1982;47:412-6.

72. Semenza GL. Life with oxygen. Science 2007;318:62-4.

73. DeCavanagh F.M, Inserra F, Ferder M, Ferder L. From mitochondria to disease: role of the renin-angiotensin system. Am J Nephrol 2007;27:545-53.

74. Eckardt KU, Bernhardt WM, Weidemann A, Warnecke C, Rosenberger C, Wiesener MS, William C. Role of hypoxia in the pathogenesis of renal discase. Kidney Int Suppl 2005;S-46-S-51.

75. Kinne-Safran E. Renal H+ ATPase. NY Acad Sci 1989;574: 189-99.

76. Ermak G, Davies KJ. Calcium and oxidative stress: from cell signaling to cell death. Mol Immunol 2002;38:713-21 .

77. Taylor CT. Mitochondria and cellular oxygen sensing in the HIF pathway. Biochem J 2008;409:19-26.

78. Rankinen T, Hietanen E, Väisänen S, Lehtiö M, Penttilä I, Bouchard C, Rauramaa R. Relationship between lipid peroxidation and plasma fibrinogen in middle-aged men. Thromb Res 2000;99:453-9.

79. Pafett ML, Walker BR. Vascular adaptions to hypoxia: modular and cellular mechanisms regulating vascular tone. Essays Biochem 2007;43:105-19.

80. Palm F, Teerlink T, Hansell P. Nitric oxide and kidney oxygenation. Curr Opin Nephrol Hypertens 2009;18:68-73.

81. Krüger R, Schütte R, Huismann HW, van Rooyen JM, Malan MT, Fourie CM, Lou WR, van der Westhuizen FH, van Deventer CA, Malan I, Schütte AM. Associations between reactive oxygen species, blood pressure and arterial stiffness in black South Africans: the SABPA study. J Hum Hypertens 2011, Jan 27. Epub ahead of print.

82. Anderson HC. Calcific diseases. A concept. Arch Pathol Lab Med 1983;107:341-8.

83. Patschan D, Patschan S, Gobe BB, Chintala S, Goligorsky MS. Uric acid heralds ischemic tissue injury to mobilize endothelial progenitor cells. J Am Soc Nephrol 2007;18:1516-24.

84. Öhman S, Larsson I, Tiselius HG. Clinical significance of phosphate in calcium oxalate urinary calculi. Ann Clin Biochem 1991;28:59-63.

85. Tiselius HIG. Is precipitation of calcium phosphate an important factor for the development of calcium oxalate stones in the urinary tract? Front Biosci 2003;8:326-32.

86. Baumann JM, Affolter B, Caprez U, Lauper D, Maier F. Hydroxyapatite induction and secondary aggregation of calcium oxalate, two important processes in calcium stone formation. Utrol Res 2001;29:417-22.

87. Achilles W, Jöckel U, Schaper A, Burk M, Riedmiller H. In vitro formation of "urinary stones". Gencration of spherulites of calcium phosphate in gel and overgrowth of calcium oxalate using a new flow model of crystallization. Scanning Microsc 1995;9:577-86.

88. Kantham L, Quinn SJ, Egbuna OI, Baxi K, Butters R, Pang JL, Pollak MR, Goltzman D, Brown EM. The calciumsensing receptor (CaSR) defends against hypercalcemia independently of its regulation of parathyroid hormone secretion. Am J Physiol Endocrinol Metab 2009;297:E915E923.

89. Giachelli CM. Vascular calcification: in vitro evidence for the role of inorganic phosphate. J Am Soc Nephrol 2003;9 Suppl 4: S300-S304.

90. Förstermann U. Nitric oxide and oxidative stress in vascular discase. Pflügers Arch 2010;459:923-39.

91. O'Brien ER, Garvin MR, Stewart DK, Hinohara 'T', Simpson JB, Schwartz. SM, Giachelli CM. Osteopontin is synthesized by macrophage, smooth muscle and endothelial cells in primary and restenotic human carotid artery plaques. Arterioscler Thromb 1994;14:1648-56.

92. Miller NL, Williams JC, Evan AP, Bledsoe SB, Coc FL, Worcester EM, Munch LC, Handa SE, Lingeman JE. In idiopathic calcium oxalate stone formers, unattached stones show evidence of having originated as attached stones on Randall's plaque. BJU Int 2010;105:242-5.

93. Evan AP, Coe FL, Rittling SR, Bledsoe SM, Shao Y, Lingeman JE, Worcester EM. Apatite plaque particles in inner medulla of kidneys of calcium oxalate stone formers: osteopontin localization. Kidney Int 2005;68:145-54.

94. Mo L, Liaw L, Evan AP, Sommer AJ, Lieske JC, Wu XR. Renal calcinosis and stone formation in mice lacking osteopontin, Tamm-I Iorsfall protein or both. Am J Physiol Renal Physiol 2007;293:F1935-F1943.

95. Berlett BS, Stadtman ER. Protein oxidation in aging, disease and oxidative stress. J Biol Chem 1997;272:20313-6.

96. Jono S, Peinado C, Giachelli CM. Phosphorylation of ostepontin is required for inhibition of vascular smooth muscle cell calcification. J Biol Chem 2000;275:20197-203.

97. Amlal H, Ledoussal C, Sheriff S, Shull GE, Soleimani M. Downregulation of renal AQP2 water channel and NKCC2 in mice lacking the apical $\mathrm{Na}^{+}-\mathrm{H}^{+}$exchanger NHE3. J Physiol 2003;553:511-22.

98. Pacher P, Beckman JS, Liaudet L. Nitric oxide and peroxynitrate in health and disease. Physiol Rev 2007;87:315-424.

99. Kanabrocki EL, Third JLHC, Ryan MD, Nemchausky BA, Shirazi P, Schevi LE, McCormick JB, Hermida RC, Bremner WF, Hoppensteadt DA, Fareed J, Olwin JH. Circadian relationship of serum uric acid and nitric oxide. JAMA 2000;283:2240-1.

100. Kumar V, Farcll G, Yu S, Harrington S, Fit»patrick L, Rzewuska E, Miller VM, Jieske JC. Cell biology of renal calcification: contribution of crystal transcytosis, cell-mediated calcification, and nanoparticles. J Investig Med 2006; $54: 412-24$

101. Schopper M, Shroff RC, Hofbauer LC, Shanahan CM. Exploring the biology of vascular calcification in chronic kidney disease: what's circulating? Kidney Int 2008;73:384-90.

102. Levy ED, Landry CR, Michnick SW. Signaling through cooperation. Science 2010;328:983-4.

103. Rappaport SM, Smith MT. Environment and disease risk. Science 2010;330:460-1.

Received: April 21, 2011 / Accepted: April 30, 2011

Address for correspondence:

Paul O. Schwille, M.D.

5, Finkenweg

91080 Uttenreuth / Erlangen

Germany

Phone: +49-(0)9131-59790

Fax: +49-(0)9131-533331

E-mail: ml.rasenack@web.de 
I. Complementary data of urine (Fig. 1, f-2; Table 2a) and plasma (Table 2b). For other informations see there.

\begin{tabular}{|c|c|c|c|c|c|c|c|c|c|c|c|c|c|c|}
\hline \multirow[b]{2}{*}{ Code } & \multirow[b]{2}{*}{$\begin{array}{l}\text { Markers } \\
\text { Strata }\end{array}$} & \multicolumn{8}{|l|}{ Urine } & \multicolumn{5}{|l|}{ Plasma } \\
\hline & & $\begin{array}{l}\mathrm{HX} \\
\mu \mathrm{M}\end{array}$ & $\begin{array}{l}\mathrm{XA} \\
\mu \mathrm{M}\end{array}$ & $\begin{array}{l}\mathrm{UA} \\
\mu \mathrm{M}\end{array}$ & $\begin{array}{l}\text { Ox } \\
\mu \mathrm{M}\end{array}$ & $\begin{array}{l}\text { Cit } \\
\mathrm{mM}\end{array}$ & $\begin{array}{l}\mathrm{Na} \\
\mathrm{mM}\end{array}$ & $\begin{array}{l}\mathrm{K} \\
\mathrm{mM}\end{array}$ & $\begin{array}{l}\mathrm{Mg} \\
\mathrm{mM}\end{array}$ & $\begin{array}{l}\mathrm{Mg} \\
\mathrm{mM} \cdot \mathrm{l}^{-1}\end{array}$ & $\begin{array}{l}\mathrm{Ox} \\
\mu \mathrm{M} \cdot 1^{-1}\end{array}$ & $\begin{array}{l}\text { AVP } \\
\mathrm{pg} \cdot \mathrm{ml}^{-1}\end{array}$ & $\begin{array}{l}\text { Osmolarity } \\
\mathrm{mOsm} \cdot \mathrm{l}^{-1}\end{array}$ & $\begin{array}{l}1,25(\mathrm{OH})_{2} \mathrm{D} \\
\mathrm{pg} \cdot \mathrm{ml}^{-1}\end{array}$ \\
\hline \multirow[t]{4}{*}{ A } & \multicolumn{14}{|l|}{ P-UA } \\
\hline & $\mathrm{L}$ & $12.4(0.9)[29]$ & $7.3(0.6)[29]$ & $378(12)$ & $24(3)$ & $0.31(0.02)$ & $13(1)$ & $8(0.3)$ & $0.28(0.01)$ & $0.85(0.01)$ & $1.74(0.08)[25]$ & $4.7(0.5)[26]$ & $294(1.2)[26]$ & $52(2)[74]$ \\
\hline & $\mathrm{H}$ & $11.3(0.7)[34]$ & $5.4(0.6)[34]$ & $404(18)$ & $21(1)$ & $0.27(0.01)$ & $12(1)$ & $8(0.3)$ & $0.14(0.01)$ & $0.85(0.01)$ & $1.63(0.10)[27]$ & $4.8(0.5)[31]$ & $296(0.3)[29]$ & $56(2)[72]$ \\
\hline & $\mathrm{p}$ & 0.15 & $0.005^{\mathrm{d}}$ & 0.12 & 0.18 & 0.04 & 0.10 & 0.12 & 0.02 & 0.32 & 0.19 & 0.43 & 0.08 & 0.13 \\
\hline \multirow[t]{4}{*}{ B } & \multicolumn{14}{|l|}{ U-MDA } \\
\hline & L & $12.1(0.9)[27]$ & $5.9(0.7)[27]$ & $351(13)$ & $24(3)$ & $0.26(0.01)$ & $11(1)$ & $7(0.3)$ & $0.24(0.01)$ & $0.85(0.00)$ & $1.69(0.11)[22]$ & $5.6(0.6)[24]$ & $296(1.2)[25]$ & $54(2)[76]$ \\
\hline & $\mathrm{H}$ & $11.7(0.7)[36]$ & $6.6(0.5)[36]$ & $430(16)$ & $21(1)$ & $0.31(0.01)$ & $14(1)$ & $9(0.3)$ & $0.27(0.01)$ & $0.86(0.01)$ & $1.69(0.08)[30]$ & $4.2(0.3)[33]$ & $295(1.0)[30]$ & $54(2)[70]$ \\
\hline & $\mathrm{p}$ & 0.32 & 0.21 & $<0.001$ & 0.16 & 0.009 & 0.001 & 0.001 & 0.04 & 0.04 & 0.49 & 0.01 & 0.28 & 0.40 \\
\hline \multirow[t]{4}{*}{ C } & \multicolumn{14}{|c|}{ U-MDA/P-UA } \\
\hline & L & $11.0(0.7)[31]$ & $4.9(0.5)[31]$ & $361(13)$ & $24(3)$ & $0.26(0.01)$ & $11(1)$ & $7(0.3)$ & $0.23(0.01)$ & $0.84(0.00)$ & $1.56(0.08)[24]$ & $5.0(0.6)[27]$ & $296(1.1)[27]$ & $53(2)[74]$ \\
\hline & $\mathrm{H}$ & $12.6(0.9)[32]$ & $7.7(0.6)[32]$ & $421(17)$ & $21(1)$ & $0.32(0.02)$ & $15(1)$ & $9(0.3)$ & $0.29(0.01)$ & $0.86(0.01)$ & $1.79(0.09)[28]$ & $4.2(0.3)[30]$ & $295(1.1)[28]$ & $55(2)[72]$ \\
\hline & $\mathrm{p}$ & 0.09 & $<0.001$ & 0.002 & 0.16 & 0.001 & 0.001 & 0.001 & 0.001 & 0.02 & 0.04 & 0.02 & 0.19 & 0.17 \\
\hline \multirow[t]{4}{*}{ D } & \multicolumn{14}{|l|}{ U-NIT } \\
\hline & $\mathrm{L}$ & $11.4(0.9)[18]$ & $6.4(0.8)[18]$ & $374(15)$ & $26(4)$ & $0.29(0.02)$ & $12(1)$ & $7(0.4)$ & $0.24(0.01)$ & $0.85(0.01)$ & $1.65(0.11)[19]$ & $5.0(0.8)[17]$ & $293(1.4)[20]$ & $56(3)[57]$ \\
\hline & $\mathrm{H}$ & $12.2(0.8)[27]$ & $6.7(0.6)[27]$ & $404(22)$ & $21(1)$ & $0.30(0.02)$ & $13(1)$ & $8(0.4)$ & $0.28(0.02)$ & $0.86(0.01)$ & $1.65(0.09)[27]$ & $4.6(0.4)[25]$ & $297(0.9)[25]$ & $53(2)[55]$ \\
\hline & $\mathrm{p}$ & 0.26 & 0.38 & 0.13 & 0.04 & 0.34 & 0.07 & 0.02 & 0.02 & 0.20 & 0.49 & 0.30 & 0.02 & 0.21 \\
\hline \multirow[t]{4}{*}{ E } & \multicolumn{14}{|c|}{ U-NIT/P-UA } \\
\hline & $\mathrm{L}$ & $11.2(0.9)[17]$ & $5.5(0.9)[17]$ & $384(22)$ & $26(4)$ & $0.29(0.02)$ & $12(1)$ & $12(0.7)$ & $0.23(0.01)$ & $0.85(0.01)$ & $1.47(0.09)[18]$ & $4.8(0.7)[17]$ & $294(1.6)[19]$ & $55(3)[57]$ \\
\hline & $\mathrm{H}$ & $12.3(0.8)[28]$ & $7.2(0.6)[28]$ & $394(19)$ & $21(1)$ & $0.29(0.02)$ & $13(1)$ & $8(0.4)$ & $0.29(0.02)$ & $0.86(0.01)$ & $1.77(0.09)[28]$ & $4.7(0.5)[25]$ & $296(0.8)[26]$ & $53(2)[55]$ \\
\hline & $\mathrm{p}$ & 0.20 & 0.05 & 0.35 & 0.04 & 0.37 & 0.10 & 0.19 & 0.005 & 0.10 & 0.02 & 0.43 & 0.19 & 0.31 \\
\hline
\end{tabular}

Shaded areas: parameters supposedly participating in IRCU pathogenesis (see also APP III). 
II. Renal fractional excretion (FE) of substances selected from Tables $2 a, 2 b$, APPENDIX I. For other informations see there.

\begin{tabular}{|c|c|c|c|c|c|c|c|c|c|}
\hline Code & $\begin{array}{r}\text { Markers } \\
\text { Strata }\end{array}$ & $\begin{array}{l}\text { FE-UA } \\
\%\end{array}$ & $\begin{array}{l}\text { FE-Ox } \\
\%\end{array}$ & $\begin{array}{l}\text { FE-Cit } \\
\%\end{array}$ & $\begin{array}{l}\text { FE-Ca } \\
\%\end{array}$ & $\begin{array}{l}\text { FE-Pi } \\
\%\end{array}$ & $\begin{array}{l}\text { FE-Na } \\
\%\end{array}$ & $\begin{array}{l}\text { FE-K } \\
\%\end{array}$ & $\begin{array}{l}\text { FE-Mg } \\
\%\end{array}$ \\
\hline \multirow[t]{4}{*}{ A } & P-UA & & & & & & & & \\
\hline & $\mathrm{L}$ & $8.4(0.3)$ & $115(11)$ & $23(2)$ & $1.6(0.1)$ & $8.5(0.5)$ & $0.67(0.04)$ & $13.2(0.6)$ & $2.8(0.1)$ \\
\hline & $\mathrm{H}$ & $7.4(0.4)$ & $104(8)$ & $18(2)$ & $1.5(0.1)$ & $9.0(0.6)$ & $0.64(0.04)$ & $13.7(0.7)$ & $2.7(0.2)$ \\
\hline & $\mathrm{p}$ & $0.006^{\mathrm{d}}$ & 0.20 & 0.05 & 0.11 & 0.25 & 0.34 & 0.28 & 0.38 \\
\hline \multirow[t]{4}{*}{ B } & U-MDA & & & & & & & & \\
\hline & $\mathrm{L}$ & $7.5(0.3)$ & $95(10)$ & $20(2)$ & $1.6(0.1)$ & $8.4(0.5)$ & $0.61(0.04)$ & $12.5(0.6)$ & $2.7(0.1)$ \\
\hline & $\mathrm{H}$ & $8.3(0.4)$ & $120(9)$ & $21(2)$ & $1.6(0.1)$ & $9.0(0.5)$ & $0.70(0.04)$ & $14.3(0.7)$ & $2.8(0.2)$ \\
\hline & $\mathrm{p}$ & 0.05 & $0.02^{\mathrm{d}}$ & 0.34 & 0.42 & 0.20 & 0.06 & 0.02 & 0.22 \\
\hline \multirow[t]{4}{*}{ C } & U-MDA/P-UA & & & & & & & & \\
\hline & L & $7.2(0.3)$ & $103(9)$ & $19(2)$ & $1.5(0.1)$ & $8.4(0.5)$ & $0.60(0.04)$ & $12.5(0.6)$ & $2.6(0.1)$ \\
\hline & $\mathrm{H}$ & $8.6(0.4)$ & $115(10)$ & $22(2)$ & $1.6(0.1)$ & $9.0(0.5)$ & $0.70(0.04)$ & $14.3(0.6)$ & $2.9(0.1)$ \\
\hline & p & 0.002 & $0.20^{d}$ & 0.14 & 0.23 & 0.22 & 0.04 & 0.002 & 0.05 \\
\hline \multirow[t]{4}{*}{ D } & U-NIT & & & & & & & & \\
\hline & L & $8.1(0.4)$ & $107(12)$ & $24(3)$ & $1.6(0.1)$ & $8.6(0.6)$ & $0.62(0.04)$ & $13.1(0.7)$ & $2.6(0.2)$ \\
\hline & $\mathrm{H}$ & $7.5(0.4)$ & $114(9)$ & $20(2)$ & $1.5(0.1)$ & $8.9(0.6)$ & $0.63(0.04)$ & $13.4(0.7)$ & $2.7(0.2)$ \\
\hline & $\mathrm{p}$ & 0.14 & $0.28^{d}$ & 0.12 & 0.18 & 0.34 & 0.43 & 0.40 & 0.38 \\
\hline \multirow[t]{4}{*}{ E } & U-NIT/P-UA & & & & & & & & \\
\hline & L & $7.9(0.5)$ & $111(11)$ & $22(3)$ & $1.6(0.1)$ & $8.6(0.6)$ & $0.63(0.04)$ & $13.6(0.7)$ & $2.6(0.2)$ \\
\hline & $\mathrm{H}$ & $7.7(0.3)$ & $112(9)$ & $21(2)$ & $1.5(0.1)$ & $8.9(0.5)$ & $0.63(0.05)$ & $12.9(0.7)$ & $2.8(0.2)$ \\
\hline & $\mathrm{p}$ & 0.35 & $0.47^{\mathrm{d}}$ & 0.38 & 0.23 & 0.39 & 0.48 & 0.73 & 0.26 \\
\hline
\end{tabular}

Shaded areas: parameters supposedly participating in IRCU pathogenesis (see also APP III). 
III. Simple correlation of 33 paired observations and components of MRA; *: For abbreviations and dimensions see Tables 1, 2a, 2b, APP I, II; **: IRCU area considered; ${ }^{+}$: 法 $\log _{10}$ data.

\begin{tabular}{|c|c|c|c|c|c|c|c|c|c|c|c|c|c|c|}
\hline & & Variables* & & SF & & & & & SB & & & & & \\
\hline $\begin{array}{l}\text { Posi- } \\
\text { tions }\end{array}$ & Blocks** & Influential & Dependent & $\mathrm{n}$ & $\mathrm{r}^{+}$ & $\mathrm{p}^{+}$ & beta $^{++}$ & $\mathrm{p}^{++}$ & $\mathrm{n}$ & $r^{+}$ & $\mathrm{p}^{+}$ & beta $^{++}$ & $\mathrm{p}^{++}$ & Remarks \\
\hline 1 & & FE-Na & $\mathrm{U}-\mathrm{pH}$ & 79 & 0.22 & 0.05 & -0.12 & 0.38 & 75 & 0.12 & 0.31 & -0.004 & 0.98 & \\
\hline 2 & & FE-K & $\mathrm{U}-\mathrm{pH}$ & 77 & 0.32 & 0.005 & 0.32 & 0.01 & 55 & 0.19 & 0.11 & 0.19 & 0.27 & \\
\hline 3 & & B-pH & $\mathrm{U}-\mathrm{pH}$ & 79 & 0.28 & 0.01 & & & 75 & 0.01 & 0.93 & & & \\
\hline 4 & "Acid- & $\mathrm{B}-\mathrm{HCO}_{3}^{-}$ & U-pH & 79 & 0.38 & 0.001 & 0.36 & $<0.001$ & 75 & 0.09 & 0.94 & -0.06 & 0.64 & \\
\hline 5 & Base" & $\mathrm{B}-\mathrm{HCO}_{3}^{-}$ & $\mathrm{U}_{\mathrm{M}}$ & 79 & 0.28 & 0.01 & 0.09 & 0.45 & 75 & 0.07 & 0.55 & -0.23 & 0.07 & \\
\hline 6 & & $\mathrm{U}-\mathrm{Na}^{\mathrm{x}}$ & U-Volume ${ }^{\mathrm{x}}$ & 79 & 0.49 & $<0.001$ & 0.35 & $<0.001$ & 75 & 0.58 & $<0.001$ & 0.04 & 0.80 & \\
\hline 7 & & FE-Na & U-Volume ${ }^{\mathrm{x}}$ & 79 & 0.31 & 0.006 & & & 79 & 0.31 & 0.001 & & & \\
\hline 8 & & $(\mathrm{U}-\mathrm{HX}+\mathrm{U}-\mathrm{XA})^{\mathrm{x}}$ & U-pH & 33 & 0.44 & 0.01 & & & 30 & 0.36 & 0.05 & & & a \\
\hline 1 & & SS-CaOx & D-BP & 61 & -0.31 & 0.01 & & & 62 & -0.15 & 0.24 & & & \\
\hline 2 & & U-MDA & D-BP & 65 & 0.29 & 0.02 & 0.27 & 0.12 & 65 & 0.16 & 0.21 & -0.12 & 0.31 & \\
\hline 3 & "Blood & P-PTH & D-BP & 64 & 0.27 & 0.03 & & & 63 & 0.17 & 0.20 & & & \\
\hline 4 & pressure, & U-NIT $^{\mathrm{x}}$ & FE-UA ${ }^{x}$ & 52 & -0.29 & 0.03 & 0.02 & 0.90 & 65 & 0.04 & 0.77 & 0.08 & 0.50 & \\
\hline 5 & Uric acid" & P-UA & D-BP & 65 & 0.26 & 0.04 & & & 65 & 0.04 & 0.60 & & & \\
\hline 6 & & BMI & D-BP & 65 & 0.25 & 0.05 & 0.13 & 0.41 & 65 & 0.47 & $<0.001$ & 0.48 & $<0.001$ & \\
\hline 7 & & BMI & P-UA & 79 & 0.29 & 0.01 & -0.29 & 0.05 & 75 & 0.26 & 0.02 & -0.40 & $<0.001$ & \\
\hline 1 & & U-NIT ${ }^{x}$ & $\mathrm{P}_{\mathrm{NP}}$ & 52 & -0.31 & 0.02 & -0.33 & 0.34 & 65 & 0.02 & 0.88 & -0.53 & 0.07 & \\
\hline 2 & & $\mathrm{U}^{-M^{\prime}}{ }^{\mathrm{x}}$ & $\mathrm{P}_{\mathrm{NP}}$ & 79 & -0.13 & 0.25 & -0.79 & 0.07 & 75 & 0.31 & 0.007 & 1.15 & 0.004 & \\
\hline 3 & & $(\mathrm{U}-\mathrm{NIT} / \mathrm{P}-\mathrm{UA})^{\mathrm{x}}$ & $\mathrm{P}_{\mathrm{NP}}$ & 52 & -0.38 & 0.005 & -0.01 & 0.97 & 65 & -0.03 & 0.80 & 0.45 & 0.13 & b \\
\hline 4 & "Protein" & $(\mathrm{U}-\mathrm{MDA} / \mathrm{P}-\mathrm{UA})^{\mathrm{x}}$ & $\mathrm{P}_{\mathrm{NP}}$ & 79 & -0.26 & 0.02 & -0.91 & 0.04 & 75 & 0.22 & 0.06 & -1.02 & 0.02 & c \\
\hline 5 & & P-UA & $\mathrm{P}_{\mathrm{NP}}$ & 76 & 0.38 & 0.001 & -0.23 & 0.04 & 72 & 0.12 & 0.32 & -0.15 & 0.19 & \\
\hline 6 & & $\left(\mathrm{U}_{\mathrm{NP}} / \mathrm{P}_{\mathrm{NP}}\right)^{\mathrm{x}}$ & U-Volume & 75 & -0.26 & 0.02 & 0.27 & 0.10 & 73 & -0.30 & 0.01 & -0.34 & 0.004 & \\
\hline 1 & & $\left(\mathrm{U}_{\mathrm{M}} / \mathrm{P}_{\mathrm{M}}\right)^{\mathrm{x}}$ & $\mathrm{U}_{\mathrm{M}} /(\mathrm{U}-\mathrm{Cit})^{\mathrm{x}}$ & 78 & 0.71 & $<0.001$ & 0.49 & $<0.001$ & 75 & 0.71 & $<0.001$ & 0.63 & $<0.001$ & d \\
\hline 2 & & $\left(\mathrm{U}_{\mathrm{M}} / \mathrm{P}_{\mathrm{M}}\right)^{\mathrm{x}}$ & $\mathrm{U}_{\mathrm{M}} /(\mathrm{U}-\mathrm{Mg})^{\mathrm{x}}$ & 79 & 0.71 & $<0.001$ & 0.41 & $<0.001$ & 75 & 0.63 & $<0.001$ & 0.19 & 0.26 & d \\
\hline 3 & & $\left(U_{M} / P_{M}\right)^{x}$ & $\mathrm{U}-\mathrm{pH}$ & 79 & 0.25 & 0.02 & -0.07 & 0.40 & 75 & -0.27 & 0.02 & -0.20 & 0.01 & \\
\hline 4 & "Calcium" & $\left(\mathrm{U}_{\mathrm{M}} / \mathrm{P}_{\mathrm{M}}\right)^{\mathrm{x}}$ & $(\mathrm{U}-\mathrm{Na}+\mathrm{U}-\mathrm{K})^{\mathrm{x}}$ & 79 & 0.41 & $<0.001$ & -0.03 & 0.77 & 75 & 0.06 & 0.60 & -0.22 & 0.01 & \\
\hline 5 & & $\left(\mathrm{U}_{\mathrm{M}} / \mathrm{P}_{\mathrm{M}}\right)^{\mathrm{x}}$ & $\left(\mathrm{U}_{\mathrm{NP}} / \mathrm{P}_{\mathrm{NP}}\right)^{\mathrm{x}}$ & 76 & -0.002 & 0.99 & -0.23 & 0.007 & 72 & -0.02 & 0.87 & 0.15 & 0.08 & \\
\hline 6 & & P-PTH & $\mathrm{P}_{\mathrm{M}}$ & 77 & 0.32 & 0.004 & 0.43 & 0.002 & 72 & 0.05 & 0.69 & -0.02 & 0.91 & \\
\hline 7 & & U-NIT $^{\mathrm{x}}$ & $\mathrm{P}_{\mathrm{M}}$ & 52 & -0.09 & 0.51 & -0.10 & 0.44 & 65 & -0.34 & 0.005 & -0.33 & 0.01 & \\
\hline 8 & & BMI & $\mathrm{P}_{\mathrm{M}}$ & 79 & 0.26 & 0.02 & 0.18 & 0.18 & 75 & -0.08 & 0.52 & -0.09 & 0.49 & \\
\hline 9 & & BMI & $\mathrm{U}-\mathrm{HX} \mathrm{X}^{\mathrm{x}}$ & 33 & 0.41 & 0.02 & & & 30 & -0.29 & 0.12 & & & $\mathrm{a}$ \\
\hline 10 & & U-NIT ${ }^{x}$ & P-PTH & 50 & -0.05 & 0.71 & & & 63 & -0.33 & 0.009 & & & $\mathrm{e}$ \\
\hline 11 & & $(\mathrm{U}-\mathrm{NIT} / \mathrm{P}-\mathrm{UA})^{\mathrm{x}}$ & P-PTH & 50 & -0.08 & 0.60 & & & 63 & -0.39 & 0.002 & & & e \\
\hline 12 & & P-PTH & $1,25(\mathrm{OH})_{2} \mathrm{D}$ & 73 & 0.27 & 0.02 & & & 68 & 0.25 & 0.04 & & & e \\
\hline
\end{tabular}

a: position not included in MRA (low number of observations detracts from power o: statistical testing); b, c: in SF patients a role of P-UA as antioxidant appears indeterminate;

d: positions appear modified by U-volume (see position 6 in block Protein) but were included in MRA; e: positions not included in MRA

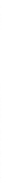

